\title{
A INDEVIDA CRIMINALIZAÇÃO DA AUTOLAVAGEM DE DINHEIRO
}

\author{
THE IMPROPER CRIMINALIZATION OF SELF-LAUNDERING
}

Luiz Phelipe Dal Santo ${ }^{1}$

Università degli Studi di Padova/IT

\section{Resumo}

O presente artigo aborda, como questão principal, a criminalização da lavagem de dinheiro cometida pelo mesmo autor do crime antecedente. No primeiro momento, expõe-se, de modo sucinto, a correspondência entre a sociedade pós-moderna e o moderno Direito Penal. Neste cenário, elementos como neoliberalismo, pretensos riscos sociais, pragmatismo, eficientismo, e populismo penal são correlacionados. Destarte, verifica-se que a presença das referidas características em conjunto não raro enseja a formulação de mecanismos penais simbólicos e de caráter utilitarista, conforme a tipificação penal da lavagem de dinheiro. Tal constatação decorre de breve abordagem quanto ao bem jurídico tutelado pelo supracitado tipo penal, percurso necessário para melhor apreciação do tema central deste estudo. Enfim passa-se a examinar a criminalização da autolavagem, cuja possibilidade fora atestada pelo Supremo Tribunal Federal, no curso do julgamento da Ação Penal 470. Em comparação com doutrinas e ordenamentos jurídicos estrangeiros, são abordadas as teses de inexigibilidade de conduta diversa - decorrente do princípio nemo tenetur se detegere -, do mero exaurimento do crime antecedente e do conflito aparente de normas, na perspectiva do pós-fato copunido e do princípio da consunção. Ao final, conclui-se pela impossibilidade de punição a tal conduta, em respeito ao princípio do ne bis in idem.

Palavras-chave

1 Mestre em "Criminologia Critica e Sicurezza Sociale. Devianza, istituzioni e interazioni psicosociali" pela Università degli Studi di Padova e pela Università di Bologna (2018); Pósgraduado em Direito Penal pela Universidade de Coimbra (2016); 
Lavagem de dinheiro. Bem jurídico. Autolavagem. Inexigibilidade de conduta diversa. Pós-fato copunido.

\section{Abstract}

This article discusses, as the main issue, the criminalization of money laundering committed by the same author of the previous crime. At first, the correspondence between the postmodern society and the modern Criminal Law is briefly explained. In this circumstance, elements such as neoliberalism, alleged social risks, pragmatism, efficiency, and criminal populism are correlated. Thus, the presence of these characteristics together often leads to the formulation of symbolic and utilitarian criminal mechanisms, just as the criminalization of money laundering. This finding stems from a brief approach regarding the legal interest protected by the aforementioned criminal type, which integrates a necessary course for a better appreciation of the central theme of this study. Subsequently, it is examined the criminalization of self-laundering, whose possibility was attested by the Supremo Tribunal Federal, in the course of the trial of Ação Penal 470. In contrast to foreign doctrines and legal systems, it analyses the thesis of unenforceability of adverse conduct (arising from the nemo tenetur se detegere principle), of exhaustion of antecedent crime and of the apparent conflict of rules (from the perspective of the co-punished post-facto). In the end, it is concluded that the author who committed the previous crime could not be punished for self-laundering, in respect of the ne bis in idem principle.

\section{Keywords}

Money laundering. Legal interest. Self-laundering. Unenforceability of adverse conduct. Co-punished post facto.

\section{INTRODUÇÃO}

No presente século, a criminalidade econômica, também chamada de crimes de colarinho branco, assume, definitivamente, papel de destaque no Brasil. Em âmbito acadêmico, cursos de Direito Penal Econômico despontam entre os mais procurados. Considerando uma conjuntura mais ampla, a questão tornou-se principal temática 
dos telejornais. Consequentemente, temas como corrupção e lavagem de dinheiro deixaram de ser exclusividades de escritórios de advocacia e hoje são abordados cotidianamente por especialistas de assuntos tratados em mesas de bar. Procuradores da República e Juízes Federais, como atores do simbólico combate à criminalidade dos poderosos, ganham status de heróis. Ao que parece, este cenário coloca em risco a histórica construção dogmática do Direito Penal, sob um enfoque cada vez mais pragmático, tendo implicação direta em constantes relativizações de princípios e garantias fundamentais. Transforma o Direito Penal em mecanismo de extensão do poder punitivo do Estado, quando, na verdade, deveria atuar como meio de contenção.

Não por outro motivo, merece análise, ainda que breve, a sociedade atual e o modo pelo qual esta se relaciona e transforma o Direito. Desta forma, construir-se-á uma contextualização necessária para melhor análise do tema tratado no presente artigo, qual seja, a lavagem de dinheiro, mais precisamente no que se refere à autolavagem.

\section{A SOCIEDADE PÓS-MODERNA E O MODERNO DIREITO PENAL}

Com o fim dos "tempos modernos", expressão que, referindo-se à época do capitalismo industrial, dá nome ao histórico filme de Charles Chaplin, e após o insucesso da efetivação do Estado de bem estar social, passamos ao período da pós-modernidade, representado pela notória ascensão do neoliberalismo (Cf. HARVEY, 2008; NETTO, 1995).

O liberalismo clássico, consagrado após a Revolução Francesa, possuía como corolário o trinômio igualdade-liberdade-fraternidade. Certo é que tais premissas, na prática, implicavam apenas e tão somente em igualdade jurídica e liberdade contratual (Cf. 
PACHUKANIS, 1988), e fraternidade enquanto propulsor de políticas capazes de reduzir as desigualdades, com a finalidade exclusiva de evitar eventual ruptura drástica da ordem social estabelecida. Numa comparação quanto à inverdade de tal enunciado como símbolo de uma conquista, hoje, no mundo globalizado, a liberdade de circulação sem fronteiras parece ser exclusividade do capital financeiro e seus interesses, tendo em vista a forte resistência à imigração, representada tanto pela xenofobia europeia em relação ao Oriente Médio e ao norte da África, quanto pelos Estados Unidos da América, a eleição de Donald Trump, seu discurso nacionalista e sua proposta de construção de muro a reforçar a separação entre este país e o México.

De outro tanto, a essência do neoliberalismo é caracterizada pela (i) competição irrestrita, na qual ética e lei não são instrumentos eficazes ou significativos de controle - a competição, por si só, é a própria lei -, (ii) desigualdade entre os competidores, inerente à própria estruturação do sistema e à organização social, e (iii) eficiência, cujos fins justificam os meios, e a dinâmica da economia de mercado estimula o desenvolvimento desenfreado, colocando em risco, por exemplo, o meio ambiente e a economia.

Não por outro motivo, a sociedade pós-moderna é chamada, por alguns, de sociedade de riscos (BECK, 2002), e por outros como sociedade do controle (DELEUZE, 1992). De todo modo, ambas estritamente ligadas, uma vez que, não raro, a consequência do risco é o excesso de controle. Ulrich Beck (2003, p. 23) ainda aponta como bases da sociedade pós-moderna o individualismo institucionalizado e o globalismo, como "ditadura neoliberal no mercado mundial, que, particularmente no Terceiro Mundo, suprime os já escassos fundamentos do autodesenvolvimento democrático". Por sua vez, Silva Franco (2000, p. 108) assevera que a "grande concentração de capitais, mobilidade acelerada desses capitais e generalização célere da 
comunicação constituem o tripé do novo modelo capitalista gerador de um poder econômico global”.

Com efeito, a propagação de medo e insegurança gerados pelos supostos riscos da atual sociedade demanda, conforme acima mencionado, um instrumento de controle capaz de restabelecer a confiança e a segurança social, tendendo ao "castigo naturalizado" (Cf. PASSETTI, 1999). Nesta conjuntura, tem-se o fenômeno por SilvaSánchez (2013) chamado de expansão do Direito Penal ou, por uma perspectiva mais crítica, aquilo que Fábio Roberto D’ávila (2013, p. 2) afirma ser "o surgimento de um direito penal de traços não democráticos". De tal sorte que o Direito Penal - em razão do discurso de medo - ganhou status de único instrumento de combate à criminalidade moderna, em que pese ser notadamente fadado ao fracasso, uma vez que, como sabido, sua intervenção ocorre sempre em momento posterior ao cometimento dos delitos e, conforme apontado pela Criminologia Crítica, a pena, como resposta do Direito Penal à violação das leis, não apresenta qualquer resultado significativo enquanto mecanismo de prevenção de crimes.

Não é demasiado afirmar que as principais consequências do neoliberalismo são: a criação de "novos tipos penais em âmbitos como o meio ambiente, a economia, o processamento de dados, [...] mercado exterior, enfim, tudo o que se refere à chamada 'criminalidade organizada”" (HASSEMER apud BOZZA e ZILIO, 2014, p. 393); e a promoção da segurança pública, até então considerada como atividade-meio ou secundária do Estado, ao grau de atividade fim (CiRINO DOS SANTOS apud Zilio e BozZA, 2014, p. 393), isto é, passa-se da segurança aos direitos para o direito à segurança. A proteção social contra a criminalidade passa a ser "uma causa mais justa que qualquer outra" (CHRISTIE, 1998, p. 181). 
Destarte, Mir Puig (apud BozZA e ZiLIO, 2014, p. 387) afirma que

toda manifestação do direito penal corresponde a uma determinada orientação política para o tratamento da criminalidade. Às ações políticas orientadas ao controle da delinquência chamamos política criminal; e toda política criminal decorre da política geral do Estado a que corresponde. Dessa forma, é possível afirmar que o direito penal é o reflexo da organização econômica e política do estado que o produz.

Nesse contexto, associado ao sentimento de insegurança e à propagação do medo cultivados pela atuação dos meios de comunicação de massa, o sistema penal assume a função de resposta ideal ao medo da população, com a promessa de tutela social ante a sociedade de riscos, e, dentre eles, os riscos econômicos. De política criminal passamos à política penal.

D'ávila (2013) brilhantemente observa que, neste contexto, a ciência penal tem reagido de modo a atuar em nome da otimização do combate à criminalidade em detrimento à consagração de princípios e garantias penais, promovendo o utilitarismo e eficientismo do Direito Penal, cujo resultado é sua própria utilização como meio de solução de conflitos. Não raro, passa, portanto, a proceder não como ultima ratio, mas como prima, ou ainda, nas palavras de Hassemer (2008, p. 5) como "sola ratio".

Conforme sustenta Silva Sanchez (2013, p.76), "a delinquência da globalização é econômica”. Nesta conjuntura, no que se refere ao moderno Direito Penal - ou Direito Penal econômico - pode-se suscitar como principais aspectos problemáticos intimamente associados: a falácia acerca dos riscos globais e da tutela do bem 
jurídico, a perpetuação da seletividade e o simbolismo dos tipos penais e da pena. Desta feita, Bozza e Zilio (2014, p. 394) concluem que

O direito penal econômico, em geral, é uma fraude. As ações perigosas para a sociedade, decorrentes do surgimento de uma economia global e do desenvolvimento tecnológico, estão no âmbito do risco permitido. Pela acessoriariedade administrativa, que caracteriza o direito penal econômico, são as agências da administração pública que, por um critério discricionário de oportunidade e conveniência, delimitam o conteúdo do injusto penal. Portanto, não se trata de proteção da sociedade contra os novos riscos (econômicos, ambientais, etc.), mas sim de um gerenciamento de quem são as pessoas autorizadas a produzirem referidos riscos.

[...] a distribuição de autorizações para a produção de grandes riscos atende exclusivamente aos interesses dos grandes conglomerados econômicos. E assim se produz a seletividade, estruturante de todo o sistema penal, também no direito penal econômico. Os criminalizados, que constituem um número desprezível, são aqueles que, na disputa política, não tiveram sucesso na tentativa de colocar seus representantes no poder do Estado.

Os delitos não constituem agressões ou ameaças a bens jurídicos concretos. Passam a ser mera desobediência a normas (agora penais) destinadas a organizar a atividade econômica. Assim, os grupos que possuem o monopólio sobre a legislação penal trabalham para impor a maior carga de deveres e responsabilidades sobre os outros 
grupos, para tornar cada vez mais complicadas e onerosas as atividades econômicas do concorrente. Assim, pode-se concluir que, da mesma forma que o direito penal clássico, o direito penal econômico possui finalidades declaradas e latentes. A função declarada de proteger bens jurídicos supraindividuais, encoberta pelo discurso de se tratar de um direito penal típico de um Estado social e democrático de Direito. No entanto, sua função real é a de assegurar a desigualdade entre os competidores dentro do modelo econômico neoliberal.

No mesmo sentido, atinente à falácia dos riscos da sociedade pós-moderna, Prittwitz (2013, p. 55) pondera que "a crise financeira, que para alguns foi uma catástrofe, não tem mudado o mundo econômico e financeiro. Os atores continuam seus 'jogos' com vantagens individualizadas (para eles mesmos) e desvantagens socializadas". Paralelamente, Mészáros (2011, p. 67-71) bem observa o desemprego crônico e a exploração como circunstâncias estruturais e programadas no sistema capitalista. Ainda, o professor alemão verifica que "90\% dos danos ao meio ambiente são resultados de atividades legais, são riscos permitidos” (PRITTWITZ, 2013 p. 63), implicando na insuficiência prática do Direito Penal como mecanismo de proteção aos aludidos riscos.

Portanto, aquilo que se pretende classificar como risco a ser tutelado nada mais é do que uma consequência própria e ínsita ao modelo do sistema socioeconômico vigente, pautado em desigualdade, competição e eficiência, como nos moldes acima descritos. Isto é, paradoxalmente (ou não), busca-se uma intervenção apenas em benefício dos próprios causadores do desequilíbrio do sistema, em plena concordância com as latentes finalidades do Direito Penal, 
expostos por Cirino dos Santos (2008, p. 6-14) através do discurso crítico da teoria criminológica da pena.

De igual modo, Zaffaroni (apud FRANCO, 2000, p. 134) se atenta à chamada criminalização dos poderosos e seu alcance restrito aos "menos poderosos, aos não poderosos que aspiram sê-lo e aos que perderam frente a outros mais poderosos, e que, além disso, terminará banalizando-se".

De outro tanto, da hipercriminalização de condutas (criminalização primária) decorre a amplitude da seletividade na atuação do sistema penal (criminalização secundária), a qual é requisito necessário para o mínimo funcionamento dos mecanismos penais na sociedade, pois, de modo contrário, criminalizar-se-ia todo e qualquer integrante da sociedade de riscos pela causação de riscos.

Outro sensível ponto referente ao Direito Penal econômico envolve a questão (da ausência) da lesão a bem jurídico. Todavia, tal abordagem será esmiuçada especificamente quanto ao delito da lavagem de dinheiro no próximo capítulo.

Não obstante, sob a mesma perspectiva da ausência de bem jurídico tutelado conciliada com a seletividade penal, emergem-se tipos penais de mero simbolismo. Nesta conjuntura, das angústias e dos anseios populares desenrola-se a tipificação de condutas com o simplório intuito a satisfazê-los, como mecanismo a dirimir tensões e a "conferir à sociedade a falsa impressão de segurança e de um legislador atuante" (BECHARA, 2011, p. 46), de modo a sustentar e legitimar, indevidamente, a expansão do poder punitivo.

Assim sendo, em sentido oposto ao que levam a crer os meios de comunicação de massa, os delitos econômicos, em regra, não 
recebem a tutela do sistema penal ${ }^{2}$, exceção feita àqueles que se tem interesse obscuro - o que, no Brasil contemporâneo, associa-se essencialmente a conotações políticas. Destarte, os crimes de colarinho branco, denunciados por Sutherland (2015, versão traduzida [1949]), ganham espaço em decorrência das próprias lutas pelo poder econômico e da judicialização da política (cf. ZAFFARONI, 1997, p. 5). No mesmo sentido, há mais de 20 anos sustentava Karam (1996, p. 80) que "o furor persecutório volta-se apenas contra adversários políticos, eventuais comportamentos não muito honestos de companheiros ou aliados sempre sendo compreendidos e justificados".

Ainda, Silva Sanchez (2013, p. 77) aponta que o caráter seletivo da repressão penal é compensado com maior severidade da sanção, isto é, $\operatorname{com}(\mathrm{o})$ o reforço do caráter simbólico da pena. De modo geral, a banalização da criminalização de condutas promovida ante a tendência ao punitivismo resulta no "fracasso" do sistema penal, reforçando o famigerado sentimento de impunidade, e sucedendo a intensificação dos temores e reinvindicações pelo recrudescimento do Direito Penal e do modelo intervencionista do Estado no que se refere ao direito de punir.

Paralelamente, em meio à efetivação do supracitado Direito Penal de traços não democráticos, o cenário em tela legitima a seletiva repressão usual e histórica do sistema penal à criminalidade da pobreza, da negritude e da juventude.

Não raro, verifica-se o duplo simbolismo dos crimes de colarinho branco: além de aparentar imparcialidade e supostamente conferir recente equilíbrio de tratamento perante a lei penal (legitimando a repressão às classes baixas, o extermínio de garantias

\footnotetext{
${ }^{2}$ Cf. INFOPEN. Disponível em: <http://www.justica.gov.br/noticias/mj-divulgara-novorelatorio-do-infopen-nesta-terca-feira/relatorio-depen-versao-web.pdf/view $>$.
} 
fundamentais e o punitivismo historicamente sustentado por anseios vindicativos como a mais eficiente - ou talvez única - resposta estatal no "combate à criminalidade"), atribui à mínima parcela de agentes e condutas criminalizados a culpa pela falência do sistema, afastando dos efeitos causados por ações legais o insucesso da sociedade pósmoderna.

Por fim, conforme precisa conclusão de Prittwitz (2013, p. 61), "o Direito Penal, dentro do grupo de candidatos ruins no marco do Direito, na realidade, é o pior candidato para solucionar os problemas da sociedade de risco". Outrossim, esta pretensa funcionalidade do Direito Penal é oriunda do (e denota o) fracasso social quanto ao combate aos riscos e às desigualdades sistêmicos e programadas do neoliberalismo.

\section{LAVAGEM DE CAPITAIS E (AUSÊNCIA DE) BEM JURÍDICO TUTELADO}

Tema do presente estudo, a criminalidade econômica é tratada por Günther Jakobs (2007) em caráter de excepcionalidade: declara-se guerra contra os inimigos, dentre os quais inseridos os donos de capital ilícito, por supostamente serem representantes da criminalidade organizada e colocarem em risco a estabilidade e a própria autonomia do Estado. Para tanto, abre-se margem à elaboração de leis ilegítimas, em razão da possibilidade de supressão de garantias constitucionais no combate ao inimigo.

Face à aludida guerra, crimes de mera conduta e de perigo abstrato, sob a roupagem de tutela a bens jurídicos difusos, são alçados à padronização das novas hipóteses de criminalização constantes do moderno Direito Penal. Nesse sentido, não é demasiado sustentar que as supracitadas características são estritamente verificadas no crime de lavagem de capitais. Assim, "a exigência da eficácia preventiva do 
direito penal impele a criminalização do perigo abstrato para áreas de pré-perigo abstrato, com a progressiva indefinição ou diluição do bem jurídico protegido" (CIRINO DOS SANTOS, Novas hipóteses..., p. 6).

Já quanto aos crimes de mera conduta, Flavio Antônio da Cruz afirma que estes

devem sofrer sanção inferior àquela cominada aos tipos penais lesivos, quanto em causa os mesmos bens jurídicos.

Assim, desde que obtido um conceito realmente denso sobre o bem jurídico, poder-se-ia cogitar de uma escala de desvalor penal, algo bastante útil para se examinar questões semelhantes à consunção e comportamentos copunidos, por exemplo. Daí que a lavagem de ativos não poderia ser punida de modo mais gravoso que os crimes antecedentes que a produziram (CRUZ, 2014, p. 389).

Neste mesmo ensejo, a ausência de concretude acerca do bem jurídico tutelado pelo delito de lavagem de capitais é exatamente a obscuridade que mais assombra os penalistas e impede (ou, ao menos, dificulta) o saneamento dos demais pontos controvertidos presentes no crime ora estudado, conforme verificar-se-á a seguir.

Maiores subsídios para a propositura de eventual solução ao conflito serão buscados, inicialmente, através de breve análise histórica.

É certo que a tipificação do delito de lavagem de capitais surgiu estritamente com o intuito de combater as organizações criminosas e o tráfico de drogas, quando se imaginava que o dinheiro ilícito proveniente da venda de entorpecentes sustentava o crime organizado de modo geral - a esta fase, chamamos primeira geração legislativa. Em momento posterior, os delitos antecedentes foram ampliados à forma 
prevista em rol taxativo - segunda geração legislativa. Por fim, o delito de lavagem de capitais encontra-se hoje em sua terceira geração legislativa, na qual se exclui a necessidade de qualquer delito antecedente expressamente previsto, incluindo a possibilidade de sua ocorrência decorrente de contravenções penais, como fruto, no Brasil, de uma opção legislativa com a finalidade específica de englobar o jogo do bicho à categoria.

Com efeito, com a ausência de resultados satisfatórios oriundos da criminalização da lavagem de dinheiro, referente ao combate às estruturas da criminalidade organizada, impôs-se "numa lógica puramente pragmática, uma extensão do âmbito do crime de branqueamento para além do que é razoável" (BRANDÃO, 2002, p. 73).

Logo, da exposta progressão histórica do crime em tela, é notória a funcionalidade expansiva de seu alcance, conforme observam Netto, Costa e Sarcedo (2013, p. 2), em razão da percepção

de que a formatação do crime de lavagem, por si só, possa significar um instrumento poderoso para a repressão de diversos tipos de criminalidade. Isto é, apercebeu-se que, por meio da tipificação da lavagem, o sistema criminal busca fechar o cerco para a ocorrência de diversas outras práticas, impedindo o aproveitamento dos produtos de crimes, impedindo o financiamento de organizações criminosas.

No que se refere à conceituação do delito de lavagem de dinheiro, Martínez-Bujan Pérez (2013, p. 249) o define, em sentido amplo, como "proceso de legitimación de los bienes de procedencia ilegal, obtenidos al margen del control de la Administración tributaria" e, em sentido estrito, como "proceso de reconversión de bienes de origen delictivo", sendo assim "el que hace necesaria la intervención del Derecho penal". 
Já Bajo Fernandéz e Bacigalupo (2001, p. 677) afirmam ser "una estratagema por la que un sujeto poseedor de dinero sustraído al control de las Haciendas públicas, lo incorpora al discurrir de la legitimidad, ocultando la infracción fiscal implícita y, en su caso, el origen delictivo de la riqueza".

Cordero Blanco (1997, p. 98) reflete acerca de ponto central para a análise do crime de lavagem de dinheiro, qual seja, da definição analítica do delito, sobre a qual, segundo o autor, "la mayoría de los autores se limitan a exponer de manera acrítica las definiciones ya acuñadas hace años". Nesse sentido, há indefinição quando ao que se pretende ocultar no branqueamento de capitais. Aponta-se como objeto da ocultação: a origem ilícita dos bens; os próprios bens de origem delitiva; tanto os bens quanto sua origem; o proprietário dos bens de origem delitiva e; por fim, tanto a origem, quanto a propriedade dos bens provenientes de ações delitivas (CORDERO BLANCO, p. 100-101).

No entanto, sendo a pretensão do agente a utilização dos bens na economia ${ }^{3}$, resultaria inútil e insuficiente a ocultação dos próprios bens, de modo a impossibilitar ao agente que disponha deles. Nesse sentido, Bajo Fernandéz e Bacigalupo (2001, p. 677) sustentam que

el dinero negro tiene necesariamente que ser blanqueado en algún momento de la vida de su titular para poder disfrutar él [...]. En dicho momento, el titular tiene dos opciones: una, confesar el origen de la riqueza $y$, al menos, responder por el delito fiscal o por cualquier otro delito que hubiera dado origen de la adquisición de

\footnotetext{
${ }^{3}$ Pois, como aponta Cordero Blanco (1997, p. 99), o objetivo do agente que lava dinheiro é "poder disfrutar de los bienes sin despertar sospechas sobre su origen".
} 
ese dinero, o proceder a lo que denominamos "blanqueo de dinero".

Nessa conjuntura, Cordero Blanco (1997, p. 101) define a origem delitiva dos bens como foco do procedimento da lavagem de dinheiro, o qual, em regra, divide-se em três estágios, conforme apresenta Brandão (2002, p. 15):

num primeiro momento, designado por colocação (placement stage), procura-se colocar os capitais ilícitos no sistema financeiro ou noutras actividades; para, numa segunda fase, chamada de transformação (layering stage), realizar as operações necessárias a ocultar essa proveniência criminosa; e num terceiro momento, o da integração (integration stage), introduzir os capitais no circuito económico legal.

De outro tanto, no que se refere à reconhecida problemática na esfera dogmática dos crimes do Direito Penal Econômico, conforme apontado por Fábio Antonio Tavares dos Santos, verifica-se a criação dos "tipos penais de captura" apresentados por Klaus Tiedemann, isto é, a tipificação de condutas com o intuito de sanar a suposta complexidade processual probatória. Alega-se dificuldade referente à produção de prova em determinados crimes e, deste modo, justifica-se a criminalização de condutas que, de forma secundária, busca o resultado de crimes anteriores. Nesse sentido, "há, assim, grande preocupação com os delitos de lavagem de dinheiro, de sonegação fiscal e mesmo com a evasão de divisas, que são crimes econômicos típicos e possibilitam o aparato persecutório criar linhas e barreiras legislativas para o combate àquilo que não se consegue diretamente coibir [...]" (SANTOS, 2015, p. 26). Porém o autor discorda que,

em Direito Penal Econômico, a prova seja um empecilho. O que há é um generalizado descaso com a 
investigação, em que órgãos persecutórios querem inverter o ônus probandi para o investigado e, ao mesmo tempo, pressionar o legislativo para quebra das garantias com o discurso doutrinário da impossibilidade da prova e do processar. (SANTOS, 2015, p. 28)

Em relação ao bem jurídico tutelado pelo tipo penal da lavagem de dinheiro, ordem econômica, administração da justiça, bem jurídico do crime antecedente e delito pluriofensivo são as teses mais sustentadas. Sem embargo, o único consenso doutrinário se refere à ausência de consenso. Não por outro motivo, a seguir, discorrer-se-á breve e isoladamente acerca de cada uma das hipóteses suscitadas.

\subsection{Administração da Justiça}

Autores como Martínez-Bujan Pérez (2013) e Badaró e Bottini (2012) sustentam que a criminalização da lavagem busca tutelar a administração da justiça, pois a conduta criminalizada teria o escopo de ludibriar a atividade persecutória do Estado, promovendo artifícios no sentido de lesá-la.

Não obstante, Martinelli pondera que o delito de favorecimento real, previsto no art. 348 do CP, já tutelaria a Administração da Justiça da mesma forma pela qual sustentam os defensores da presente tese, e que, caso fosse este o bem jurídico tutelado, estaríamos diante de uma "tutela em dobro", categorizando a Administração da Justiça, nas palavras de Salditt, como um "super bem jurídico" (MARTINELLI, 2011, p. 96).

De outro tanto, tem-se de igual modo a criação de tipo penal contrária à "obstrução da justiça", prevista na Lei 12.850/13 (Lei de Organização Criminosa), em seu art. 2o, §1ㅇ․ 
$\S 1$ o - Nas mesmas penas incorre quem impede ou, de qualquer forma, embaraça a investigação de infração penal que envolva organização criminosa.

Deste modo, considerando a natureza da criminalização do delito de lavagem pretensamente associada às organizações criminosas, teríamos, eventualmente, uma tripla tipificação referente à mesma questão, isto é, um "tris" in idem.

Ainda, buscando fundamentar a hipótese em tela, alega-se a inexistência do proveito do crime no tipo penal da lavagem, o que indiretamente asseguraria a funcionalidade do delito estritamente ligada à administração da justiça. No entanto, verifica-se na Exposição de Motivos da Lei no 9.613/98:

34. Observe-se que a lavagem de dinheiro tem como característica a introdução, na economia, de bens, direitos ou valores oriundos de atividade ilícita e que representaram, no momento de seu resultado, um aumento do patrimônio do agente.

Assim, a criminalização da conduta em tela tem, sim, como fundamento o aumento patrimonial do agente, o que, minimamente, afasta a pretensa direção da funcionalidade do tipo penal à hipótese aqui apresentada.

\subsection{Ordem Econômica}

Na concepção de Schmidt (2015, p. 67), ordem econômica refere-se à dimensão jurídica de política econômica, compreendendo, portanto, a tutela à "regulamentação do sistema financeiro, do mercado de capitais, da livre concorrência, do sistema tributário, do orçamento etc". No entanto, não há qualquer apontamento concreto a respeito da forma pela qual a ordem econômica é atingida pelo cometimento da lavagem de dinheiro. Não há verificações empíricas. 
Destarte, a ordem econômica, como bem jurídico, não seria sequer passível de tutela na seara penal, até mesmo em razão de sua própria vagueza conceitual.

Ademais, para se considerar a ordem econômica afetada pela lavagem de dinheiro, haveria que se distinguir a forma tentada da forma consumada, não sendo suficiente a mera ocultação ou dissimulação da natureza dos bens, como previsto no caput do art. 2o da Lei $12.683 / 12$, pois sem a inserção do capital de origem ilícita à atividade econômica (isto é, o mero ocultamento da origem de determinado bem), não haveria qualquer afetação à ordem econômica propriamente dita.

Nesta hipótese, retoma-se toda a crítica quanto aos bens jurídicos difusos. Sob uma perspectiva mais específica e corroborando a aludida tese de que os supostos riscos à ordem econômica são intrínsecos ao sistema socioeconômico vigente, temos, no mundo, diversas ocorrências e propostas de anistia que visam introduzir o dinheiro "sujo" na economia, isentando de pena e permitindo a inserção de valores provenientes de delitos os quais se propõe combater, em razão da possibilidade de, a partir da injeção do dinheiro à economia, viabilizar a cobrança de tributos sobre valores anteriormente "invisíveis", aumentando a receita estatal e, na contramão do que se pretende sustentar, acelerando a atividade econômica. Nesse sentido, "el blanqueo de dinero es, por tanto, una actividad absolutamente irrelevante desde el punto de vista jurídico penal, salvo por el valor indiciario de la comisión de un hecho delictivo" (BAJO FERNÁNDEZ; BACIGALUPO, 2001, p. 678).

Observa-se, ainda, que, não raro, "muitos setores da economia estão sob controle exclusivo de determinados grupos ou pessoas, capazes de controlar o dinheiro sujo de modo a não prejudicar seu segmento de atividades" (MARTINELLI, 2012, p. 50). De modo a 
corroborar, uma vez mais, que a ofensa aos princípios da atividade econômica (como livre iniciativa, concorrência e consumidor) é cometida no âmbito da própria legalidade, um relatório publicado em 16 de janeiro de 2017, realizado pela ONG Oxfam International, concluiu que oito homens detém a riqueza equivalente à possuída pela metade da população mundial, isto é, 3,6 bilhões de pessoas ${ }^{4}$.

\subsection{Bem jurídico do crime antecedente}

Autores como Salditt e Wessels (apud MARTINELLI, 2011, p. 7374), Greco Filho (2006), Bajo Fernandéz e Bacigalupo (2001) asseveram que o delito de lavagem de dinheiro serve como reforço à proteção do bem jurídico tutelado pelos delitos antecedentes, na medida em que sua finalidade é "impedir el delito originario que se está ocultado y se lesiona, por lo tanto, el bien jurídico de este delito" (BAJO FERNANDÉZ E BACIGALUPO, 2001, p. 684).

Greco Filho (2006, p. 163-1.4), ao analisar o originário crime de lavagem (previsto na Lei 9.613/98), afirmava que "o crime de lavagem não tem existência própria; depende da existência do crime antecedente, a cuja existência está condicionado. Existe para complementar proteção ao bem jurídico do crime anterior e evitar que daquele se venha auferir lucro impunemente". Não por outro motivo, o autor brasileiro indica que, na hipótese de autolavagem (assunto tratado no próximo capítulo), tratar-se-ia de mero exaurimento do crime antecedente, sendo "o fim desde sempre visado pelo agente, seu complemento ou, até o meio indispensável ao 'sucesso' do primeiro”.

4 Relatório completo disponível em: https://www.oxfam.org/sites/www.oxfam.org/files/file_attachments/bp-economy-for-99percent-160117-es.pdf. Visto em 20 jan 2017. 
Nota-se que a doutrina brasileira afasta a possibilidade do delito de branqueamento de capitais tutelar o mesmo bem jurídico ofendido em crime antecedente em razão da possibilidade de criminalização da autolavagem e que, portanto, o contrário significaria dupla punição pelo mesmo fato. Todavia, tal questão não é fundamento idôneo. Inclusive, a leitura inversa deve ser feita: sabe-se que "o legislador" não possui compromisso com tal questão, conforme nota-se das infindáveis e notórias incongruências legislativas decorrentes do populismo penal. Portanto, inexistindo fundamento mais bem desenvolvido a refutar a tese atinente à possibilidade de eventual tutela do mesmo bem jurídico afetado em crime antecedente, há que se atentar para a possibilidade, sim, da ocorrência de dupla punição pelo mesmo fato.

Por outro lado, a extinção do rol de crimes antecedentes de igual modo não deve servir como argumento hábil. Neste sentido, a evolução histórica do delito de lavagem pode ser interpretada também como a substituição de eventual superproteção ao bem jurídico do crime antecedente para a atual garantia das expectativas normativas, conforme a função de prevenção geral positiva da pena (considerando a extensão de possibilidades do delito antecedente a todo e qualquer crime, isto é, como própria superproteção ao cometimento de crimes em geral), o que, erroneamente, leva alguns autores a apontarem a Administração da Justiça como bem jurídico tutelado. Trata-se, na verdade, da perfeita adaptação à tendência expansionista do moderno Direito Penal econômico.

Destarte, da Exposição de Motivos da Lei de Lavagem, extrai-se que o tipo penal desta lei se trata "de mais uma contribuição legislativa que se oferece ao País, visando ao combate sistemático de algumas modalidades mais frequentes da criminalidade organizada em nível transnacional". Isto é, buscando coibir o cometimento dos delitos antecedentes, promove-se a criminalização como instrumento de 
política criminal às avessas - pois, como assevera Ana Elisa Bechara (2011, p. 46), "tomado o Estado como instrumento a serviço dos indivíduos, a atividade político-criminal deverá estar teleologicamente orientada à busca da proteção dos respectivos direitos fundamentais, mesmo na esfera penal" -, com o propósito inicial de combater a criminalidade organizada através de uma via subsidiária, todavia sem observar os princípios fundamentais do direito. Criminaliza-se uma conduta e outras associadas à consequência da falência da persecução estatal - o produto do crime.

Tem-se, assim, uma espécie de opção pela persuasão ao não cometimento de delitos. Isto é, a normatividade do fato típico serviria como prevenção ao cometimento dos delitos prévios, pois tornar-se-ia mais improvável o êxito em utilizar o dinheiro de origem delitiva. A mensagem extraída da norma do tipo penal do crime de lavagem é: "não cometa crimes com o intuito de obter lucro, pois, ainda que não punido o crime antecedente, a utilização deste bem seria, em ação diversa, igualmente criminalizada".

Portanto, estar-se-ia, de alguma forma, associado à tutela do mesmo bem jurídico do crime antecedente, ainda que de forma indireta ou subsidiária.

No plano prático, a hipótese de lesão ao mesmo bem jurídico do crime antecedente implica necessariamente na violação ao ne bis in idem. Portanto, ao menos no âmbito teórico, não se poderia sustentar ser este o bem jurídico tutelado. Nota-se, no entanto, que a argumentação teórica é, muitas vezes, apenas um mecanismo de legitimação, e não o elemento causal da tipificação penal de uma conduta (conforme será indicado em momento posterior). De tal sorte, como instrumento de legitimação, tal hipótese não poderia prosperar.

\subsection{Pluriofensividade}


De modo conciso, Martinelli (2011, p. 100) conclui que "a opção por vários bens [jurídicos tutelados pelo tipo penal da lavagem de dinheiro] verifica-se como a 'válvula de escape' da dificuldade de legitimar um único bem a ser tutelado". Nesse sentido, alguns autores procuram englobar tanto a administração da justiça, quanto a ordem econômica como bens jurídicos protegidos pela tipificação penal do crime de lavagem, em razão de não encontrarem fundamentações suficientemente concretas a sustentar eventual bem jurídico necessário para a tipificação penal da conduta em tela.

De modo inverso, ao sustentar uma exclusiva hipótese de bem jurídico tutelado, grande parte da doutrina apresenta ponderações capazes de afastar todas as demais teses por outros autores defendidas. Ora, os esforços doutrinários não deveriam, portanto, ser direcionados ao sentido oposto ao que caminha?

Outrossim, se a finalidade da lei não é a tutela de relevante bem jurídico através da normatividade do tipo penal, tem-se um tipo penal ilegítimo e, nesse sentido, a infindável busca pela legitimação do delito em tela representa a covardia da cessão aos anseios populares e ao populismo penal.

\subsection{Ilegitimidade: tipo penal instrumental}

Para Juarez Cirino (2008, p. 18),

o conceito de bem jurídico, como critério de criminalização e como objeto de proteção, parece constituir garantia política irrenunciável do Direito Penal do Estado Democrático de Direito, nas formações sociais estruturadas sobre a relação capital/ trabalho assalariado, em que se articulam as classes sociais fundamentais do neoliberalismo contemporâneo. 
Ainda, aponta o autor a necessidade de se excluir a criminalização da vontade do poder, do risco abstrato e de interesses difusos, como por exemplo a economia, de modo a reafirmar os "princípios do Direito Penal do fato, como lesão do bem jurídico, e da culpabilidade, como limitação do poder de punir, excluindo a estabilização das expectativas normativas das concepções autoritárias do funcionalismo de Jakobs, por exemplo" (CIRINO DOS SANTOS, 2008, p. 17-18).

Com efeito, não se limitando ao plano teórico e em atenção à realidade fática, convém trazermos ao presente estudo a 'parábola involutiva' do bem jurídico de Luigi Ferrajoli, a qual, segundo Flavio Antônio da Cruz (2014, p. 333), consiste na

constatação de que a teoria do bem jurídico, concebida inicialmente como mecanismo de contenção do poder punitivo, tem sido empregada, em tempos recentes, muito mais para ampliá-lo.

A mencionada parábola involutiva, o processo de perversão do bem jurídico, permite constatar que, por desgraça, ele tem sido utilizado historicamente - em muitas ocasiões - não mais para reduzir o poder punitivo estatal, senão, ao contrário, para justificar e legitimar cada nova figura delitiva, ante cuja iminente sanção, os juristas penais têm corrido apressados à busca de um bem jurídico capaz de convalidá-la. Assim, de uma concepção limitadora, o bem jurídico tem passado a funcionar no sentido inverso, como instrumento de legitimação.

Atento à deturpação conceitual supracitada, Tavares (2002) defende que o bem jurídico como objeto de proteção normativa seria mera referência formal e que, portanto, careceria de pressuposto 
material, cuja fundamentação deve ser conferida pela determinação do conteúdo do injusto penal, de referencial guinado à proteção da pessoa.

Não é forçosa a interpretação de que, portanto, carece de legitimidade o delito de lavagem de dinheiro, cujo emprego direcionase à funcionalidade político-criminal: como crime de captura, cumpre função de instrumento auxiliar na atividade persecutória do Estado e, por outro lado, como forma de vedação ao proveito e à incorporação, ao patrimônio, de vantagens econômicas oriundas de delitos ${ }^{5}$, exerce reforço à função preventiva geral da pena. Não por outro motivo, certos autores sustentam que a lavagem de dinheiro é mais do que um mero tipo penal, sendo "a consagração do valho adágio de que o 'crime não deve compensar'. A criminalização da lavagem incrementa as chances de confisco do produto do crime. Se o criminoso utilizar artifícios para ocultá-lo ou dissimulá-lo ficará incurso na pena de novo crime" (MORO, 2010, p. 16).

Nos mesmos moldes, a criminalização do enriquecimento ilícito, como na forma proposta pelas "10 medidas de combate à corrupção" do MPF, por ser prova indireta da corrupção, guarda notável semelhança com a tipificação da lavagem de dinheiro. Em ambos os casos, razões pragmáticas e pretensões ontológicas são alegadas: uma forma alternativa de alcance do poder punitivo às condutas anteriores não punidas e um comportamento "em si mesmo desvalorado", como tentativa de distanciamento da tese que acusa a instrumentalidade dos tipos penais em tela como fator prevalecente (se não único) de sua criação e sustento no ordenamento jurídico penal (cf. GRECO, 2015, p. 7).

\footnotetext{
${ }^{5}$ Neste sentido, segundo Bajo Fernandéz e Bagicalupo (2012, p. 679), “el blanqueo de dinero no constituye un acto en sí mismo y está simplemente relacionado con la política de represión del fraude fiscal'.
} 
Nos auges de um Estado totalitário, a criminalização em nome do poder punitivo - extrapolando função de "mero tipo penal" resultou em tragédias como, no extremo, o holocausto, juridicamente embasado e tutelado pela tipificação das Leis de Nuremberg. Frisa-se que não se está aqui comparando o conteúdo entre tais tipificações, mas apenas apontando as graves e não impossíveis consequências de permissão da existência de tipos penais que não cumprem a função própria de um tipo penal, sem o devido respeito a todos os princípios fundamentais do Direito, inseridos em dado sistema normativo jurídico.

Ainda, a criminalização da lavagem de dinheiro é inserida no que Baratta (1994, p. 22), ao tratar da função simbólica do Direito Penal, interpreta "não tanto como um sistema de produção de segurança real dos bens jurídicos, mas sim como instrumento de resposta simbólica à exigência de pena e segurança por parte do 'público' da política”.

Roxin, em sua proposta de integração entre política criminal e sistema jurídico penal, se atenta ao limite da inserção de opções e valorações político-criminais ao sistema do direito penal, "de tal forma que a fundamentação legal, a clareza e a previsibilidade, as interações harmônicas e as consequências detalhadas deste sistema não fiquem a dever nada à versão formal-positivista de proveniência lisztiana" (Roxin, 2000, p. 20). Do mesmo modo, Martinelli (2011, p. 155) afirma que "a conjugação entre os conceitos dogmático e político-criminal é fundamental para respeitar os princípios elementares do direito penal e legitimar a norma incriminadora". Portanto, a política criminal deve ser utilizada como vetor de redução do poder punitivo, sendo certo que sua utilização é hoje fundamentada sob uma perversão sistemática, de modo direta e proporcionalmente inverso ao qual se propõe a atuar. 
Urge apontar que "a penalização de um comportamento necessita, em todo caso, de uma legitimação diferente da simples discricionariedade do legislador" (RoxIN. 2009, p. 11), e que a incriminação de condutas não deve ser vinculada "a uma função finalística de assegurar uma determinada ordem ou a consecução de ideais políticos" (TAVARES, 2002, p. 302).

É cristalina, portanto, a natureza utilitarista da criminalização da lavagem de capitais, corroborada pelo fato de que cada etapa da lavagem corresponderia a um tipo penal já existente em nosso sistema jurídico-penal. Nesse sentido, como sustenta Martinelli, aqui se enquadram os crimes de receptação, de favorecimento e contra o Sistema Financeiro. Destarte, propõe o autor a adaptação do art. 180, $\mathrm{CP}$, inserindo, como causa de aumento, o recebimento de produto de crime com finalidade de ocultação e dissimulação; ou causa de aumento de pena "quando o meio para o favorecimento (art. 349) fosse realizado por meio de transações financeiras" (MARTINELLI, 2011, p. 139/140).

Por outro lado, uma possível opção político-criminal eficiente no combate às estruturas do crime organizado e ao dinheiro de origem ilícita inserido nas atividades econômicas seria a descriminalização e regulamentação do uso de drogas, de modo a diminuir a quantidade de dinheiro lavado.

\section{Autolavagem}

Tema de divergência em esfera global, a admissibilidade da criminalização por lavagem de dinheiro ao mesmo autor do crime antecedente foi reconhecida no Brasil, pelo STF, no curso da Ação Penal 470. Tal entendimento localiza-se no mesmo sentido das jurisdições penais norte-americana, inglesa e espanhola, por exemplo. 
Em plano diverso, o direito penal germânico (§261, StGB) determina que quem for passível de punição em razão de participação em crime antecedente não será punido pela lavagem de dinheiro. Cordero Blanco acrescentava os códigos penais austríaco (§165) e sueco (art. 6, §2o do capítulo 9) dentre os que vedavam expressamente a autolavagem. Ainda, em que pese quedar silente o código suíço, a doutrina majoritária do país também afastava a punibilidade do agente que comete tanto o delito antecedente quanto o de lavagem de dinheiro (CORDERO BLANCO, 1997, p. 462).

No entanto, é possível notar a recente alteração interpretativa e/ou legislativa em alguns países que antes não admitiam a autolavagem, mas que agora a permitem. Tal conjuntura é passível de verificação através do direito penal italiano.

Há tempos, o Código Penal do país em referência, em seu artigo 648 bis, apresentava uma cláusula de reserva, a qual excluía da lista de sujeitos ativos da lavagem de dinheiro aqueles que tivessem concorrido para o crime antecedente, entendendo sê-lo um pós-fato copenado.

Não obstante, oriundo da comma 3, dell'articolo 3, della Legge 15 dicembre 2014, n. 186, o delito da autolavagem passou a ser previsto no art. 648 ter 1, do código penal italiano. Certo é que tal criminalização segue não só a tendência da europeização do direito penal, como bem atenta Helmut Satzger (2013), mas obedece também o movimento expansionista do Direito Penal da sociedade pósmoderna. De todo modo, nota-se que a pena para o delito de riciclaggio di denaro é de 4 a 12 anos, ao passo em que para o autoriciclaggio prevê-se 2 a 8 anos, denotando novamente o caráter simbólico de tal criminalização, haja vista que, ainda que afetasse qualquer bem jurídico que se pretenda sustentar, inexistiria qualquer diferenciação, nesta hipótese, quanto à sua afetação a depender do autor da conduta, a fim de justificar a aludida diminuição da pena. De modo contrário, 
concluir-se-ia pelo esgotamento do injusto penal já no crime precedente, como se demonstrará posteriormente.

Ademais, a necessidade de positivação de lei própria referente à autolavagem diz muito acerca da própria impossibilidade - em senso jurídico - de criminalização da conduta em tela. Do oposto, não haveria razão para prevê-la de modo específico no ordenamento jurídico, pois já estaria prevista no tipo geral.

De modo geral, dentre os argumentos que sustentam a inaplicabilidade da autolavagem, destacam-se a inexigibilidade de conduta diversa e o fato posterior copunido, que levam à interpretação da pretensa criminalização como autêntico bis in idem, como defendem, por exemplo, Estellita (2014) e Schorscher (2012). Nesta conjuntura, e corroborando o que assevera Greco Filho (2006, p. 164165), Fernanda Tórtima (apud FRAGOSO, 2013, p. 31) afirma não ser “justificável a punição de uma conduta, que não apenas necessariamente acompanha a conduta anterior como também lhe dá sentido".

\subsection{Inexigibilidade de conduta diversa}

Do principio nemo tenetur se detegere (do direito à não produção de provas contra si mesmo), interpreta-se não ser possível exigir de alguém que entregue ou deixe ao alcance de autoridades policiais e judiciais o resultado de crime por ele cometido.

Desta premissa, Délio Lins e Silva Junior e Marco Aurélio de Paula (2009, p. 62) defendem a ideia de que "quando o autor do crime de lavagem de dinheiro for também o executor do crime antecedente, deve ser aplicada a inexigibilidade de conduta diversa para excluir sua culpabilidade com relação ao crime de lavagem de dinheiro".

Por sua vez, Renart García, adotando o bem jurídico afetado como a administração da justiça e partindo de comparações entre a 
lavagem de dinheiro e os favorecimentos pessoal e real, também baseado na inexigibilidade de conduta diversa, aponta que não seria exigível que o autor da lavagem de dinheiro e do crime antecedente se entregasse às autoridades de persecução penal. Destarte, influenciado por Ackermann, o autor español sustenta que "la posterior dificultación de los trabajos de investigación relativos a los valores patrimoniales constituye una 'consecuencia natural' del injusto del hecho previo" (RENART GARCÍA, 1998, p. 149/150).

Não muito distante, Cordero Blanco (1997, p. 474) expõe que no se puede castigar a un delincuente que ha cometido un delito por encubrir los bienes derivados del mismo, pues ello equivaldría a exigirle una declaración contra sí mismo. En cambio, sí se puede sancionar al delincuente que realiza otros delitos distintos para encubrir los bienes, tales como estafas, etc. El mero hecho de autoencubrirse, sin cometer para ello otros delitos, da lugar a una situación de no exigibilidad de una conducta diferente.

De modo diverso, Bottini e Badaró entendem ser possível a possibilidade da dupla punição (autolavagem), pois, segundo eles, "o bem jurídico protegido pela norma em comento (administração da Justiça) é, em regra, diferente daquele afetado pela infração anterior, e a distinção material permite a punição em concurso material sem que exista o bis in idem". Todavia, de modo questionável, buscam diferenciar a autolavagem do favorecimento real - no qual não incide a criminalização ao agente do ilícito antecedente, mas, do mesmo modo, tutela bem jurídico diverso do crime anterior - por dois motivos: primeiro pois "no favorecimento real o tipo penal expressamente afasta a punição do autor original, enquanto na lavagem de dinheiro a ressalva inexiste"; após, sustentam que, ainda 
que não fosse expressamente afastada a possibilidade de criminalização do autor do crime antecedente, seria cabível a inexigibilidade de conduta diversa, "pois não parece possível impor ao agente de um delito prévio que não tome medidas e precauções para tornar seguro o proveito dele decorrente". No entanto, entendem que na lavagem de dinheiro, tratar-se-ia de uma "lesão qualificada à administração da Justiça que afasta a inexigibilidade de conduta diversa". (BADARÓ; BOTTINI, 2012, p. 74).

E exatamente aqui incide o primeiro ponto de divergência da presente hipótese. A supracitada "lesão qualificada", em palavras distintas, é usualmente representada pela doutrina com a seguinte abordagem:

sólo cuando la legalización de bienes ostenta ciertos caracteres cualitativos y cuantitativos puede hablarse com propiedad de um ilícito autónomo, dotado de un contenido material propio, que debe castigarse con independencia de quién sea el sujecto activo (IGNACIO DE LA TORRE; FABIÁN CAPARROS, 2010, p. 82).

Desta construção lógica, podemos concluir que a tese sustentada para permitir a autolavagem limitada à questão de maior relevância qualitativa e quantitativa das ações na lavagem - isto é, afastando as hipóteses mais banais ou menos formuladas, mas criminalizando atos mais efusivos através da prática de condutas penalmente típicas - deve ser encarado como próprio problema de tipicidade do crime de lavagem. Isto sem ser necessária qualquer análise mínima acerca do novo conteúdo do §2o da dita lei, o qual tipifica a utilização "na atividade econômica ou financeira, bens, direitos ou valores provenientes de infração penal”. Nesta hipótese, a autolavagem configura indiscutível exaurimento do crime antecedente. De outro tanto, a incriminação de agente alheio ao crime 
antecedente resultaria numa espécie de "criminalização do conhecimento", haja vista que a utilização de bens ou valores na atividade econômica ou financeira é uma atividade usual e constante do sistema socioeconômico vigente (capitalismo), de modo que o que diferenciaria a ação tipificada de ações corriqueiras seria o mero conhecimento da origem ilícita dos bens utilizados. Aqui, expande-se o dever de fiscalização a todo cidadão (auxiliando na problemática da ineficiente atividade persecutória estatal), e soluciona-se a insuficiência da tipicidade objetiva com a supervalorização do tipo subjetivo.

Busca-se, portanto, afastar a aplicação da inexigibilidade de conduta diversa pois, no caso da lavagem, a ação para se "proteger" ultrapassaria o limite permitido, haja vista que o princípio de não produzir prova contra si mesmo não concederia ao agente a possibilidade de fazê-lo através de uma conduta criminosa. Sem embargo, tal razão argumentativa representaria um ciclo em si mesmo. Bastar-se-ia criminalizar a mentira do réu em oitiva, o silêncio judicial, ou a recusa à subsunção a coleta de materiais, de modo imotivado (isto é, sem a definição própria referente à afetação de bem jurídico nas aludidas hipóteses, e sem a verificação quanto aos demais elementos dogmáticos) e como tipificação própria de uma política criminal que visa facilitar a atividade persecutória do Estado, aumentando seu poder punitivo. Nesse sentido, haveria possibilidade de que tais condutas passassem a não ser mais englobadas pelo princípio nemo tenetur se detegere.

Ora, assim como a opção por se manter silente em juízo e a negativa a submeter-se a exames que potencialmente possam produzir provas biológicas não integram qualquer tipo penal, eventuais movimentações financeiras ou depósitos de dinheiro em conta diversa também não. Igualmente, abrir uma empresa ou alugar um imóvel 
também não, e assim por diante. Por outro lado, falsidade ideológica e documental ou fraude, sim, integram tipos penais. Nesse sentido, o que se pretende punir com a autolavagem (nos moldes do critério da relevância qualitativa e/ou quantitativa) seria necessariamente uma ação já tipificada, sendo inexigível a criação de novo tipo penal para criminalizar a mesma conduta, de modo mais severo e empregado sob o pretexto do princípio da especificidade.

Superada tal questão, há que se atentar para a controversa possibilidade de extensão do princípio nemo tenetur se detegere ao plano substancial (direito material), sem restrição de sua aplicação como princípio essencialmente de âmbito processual.

Parte da doutrina refuta a possibilidade da supracitada produção de efeitos extensiva. Alega-se que sua aplicação é vinculada a eventual persecução penal (seja no âmbito policial ou no curso de ação penal) já existente e, desta forma, seria incompatível fundamentálo visando à exclusão da punição ao autor da autolavagem.

Em oposição, há autores que sustentam o direito de defesa não só na esfera processual, mas igualmente tutelando "o atual e potencial acusado em todas as suas relações com a autoridade, independentemente do processo ter-se iniciado" (BADELLINO apud QUEIJO, 2012, p. 465), como espécie de "'projeção extraprocessual' do direito à defesa” (MANZILLO apud QUEIJO, 2012, p. 466), de modo a obstar a instauração do processo. Em que pese concordar com tal atuação estendida, Maria E. Queijo (2012, p. 476) entende que o aludido princípio não deve produzir efeitos quando em causa a tentativa de ocultação de crime antecedente, em razão de possível funcionamento como estímulo à criminalidade. Tal assertiva será retomada em momento posterior.

Certo é que o princípio em tela integra os direitos de primeira geração, isto é, referente à liberdade, notadamente frente aos excessos 
e abusos do Estado, relacionando-se com a dignidade humana. Integra também o direito de defesa e o devido processo legal. Destarte, sendo este um princípio constitucional, tem "força vinculativa, determinando comportamentos e norteando a interpretação de outras normas" (QUEIJO, 2012, p. 90). É imperioso, portanto, que interfira no âmbito interpretativo atrelado aos dispositivos infraconstitucionais, como a Lei Penal e Processual Penal.

Na hipótese de se considerar a administração da justiça como, de fato, o bem jurídico tutelado pelo delito da lavagem de dinheiro, convém esclarecer que, sendo a garantia constitucional da não produção de provas contra si mesmo ínsita à construção do sistema de Justiça, entende-se que sua prática não poderia ofender a administração da justiça, uma vez que o próprio sistema jurídico o prevê e o consagra como direito fundamental. Ora, de outro modo, se se entendesse esta suposta categoria de bem jurídico (administração da justiça) como tutelada em detrimento do bem jurídico protegido pelo emprego do direito à não autoincriminação, não haveria a previsão de tal garantia. Tal preceito é corolário do Estado Democrático de Direito. Portanto, a prática do cidadão em valer-se de uma garantia fundamental consagrada pelo sistema de justiça vigente não deve ser óbice à própria administração do sistema em tela, o qual é devidamente estruturado partindo desta premissa.

Não é demasiado sustentar que, nesta conjuntura, há margem interpretativa para enquadrar a inexigibilidade de conduta diversa como causa de justificação. Nesse sentido, seria "dispensável uma enumeração taxativa de todas as causas de justificação na legislação penal, admitindo-se a exclusão da antijuridicidade de conduta quando a ação típica está autorizada pelo Direito público ou privado" (DIETER, 2008, p. 64). 
Nesta conjuntura, Dieter esclarece que a incompatibilidade entre tipo penal e garantia constitucional deve ser sanada no campo da antijuridicidade. Portanto,

é preciso avaliar se o bem jurídico afetado também pode ser identificado como um direito fundamental, individual ou coletivo. Caso contrário, não haverá antijuridicidade material, porque um sistema jurídico fundado na Constituição não pode definir como 'injusta' a preservação daqueles valores que são definidos como o limite mínimo de qualquer possibilidade de 'justiça', e deste modo a questão sequer alcança o umbral da culpabilidade (DIETER, 2008, p. 64).

Destarte, é possível que a inexigibilidade de conduta diversa fundada na garantia constitucional da não autoincriminação, passível de enquadramento como circunstância supralegal de exculpação (não prevista explicitamente no ordenamento jurídico brasileiro), interfira a própria antijuridicidade do fato, como similarmente propunha Estellita (1999), entretanto a modulando enquanto exercício regular de direito. Assim, verifica-se a confirmação - em realidade, a extrapolação - do que previu Silva Sánchez quanto às tendências do moderno Direito Penal, dentre as quais

as causas de exclusão da antijuridicidade e de culpabilidade se concebam como elementos que não somente devem ser razoavelmente alegados, senão inclusive provados pelo imputado. Isso, a partir da ideia de que a acusação somente deve provar a tipicidade, e não a antijuridicidade ou a culpabilidade, pois as eximentes (causas de exclusão da antijuridicidade ou da culpabilidade) devem ser provadas por quem as alega em sua defesa (Silva Sánchez, 2013, p. 93). 
Nessa conjuntura, em que pese demonstradas tais excludentes, razões fundadas em uma opção de política criminal, cuja utilização fundamenta a própria tipificação do delito em tela, acabam por prevalecer quando em atrito com possíveis exculpantes ou causas de justificação.

\subsection{Pós-fato copunido}

Em que pese a devida adequação da hipótese retro aos princípios fundamentais do Direito, a construção teórica de maior relevância e/ou eficácia para sustentar a inaplicação do delito de autolavagem é fundada na teoria do pós-fato copunido, cujo emprego é verificado no direito germânico.

Inicialmente, convém expor, brevemente, alguns trechos presentes na Exposição de motivos da Lei 9.613/98:

"15. As primeiras legislações a esse respeito, elaboradas na esteira da Convenção de Viena, circunscreviam o ilícito penal da 'lavagem de dinheiro' a bens, direitos e valores à conexão com o tráfico ilícito de substâncias entorpecentes ou drogas afins. Gravitavam, assim, na órbita da 'receptação' as condutas relativas a bens, direitos e valores originários de todos os demais ilícitos que não foram as espécies típicas ligadas ao narcotráfico. Essa orientação era compreensível, visto que os traficantes eram os navegadores pioneiros nessas marés $d a$ delinqüência transnacional e os frutos de suas conquistas não poderiam ser considerados como objeto da receptação convencional.

[...] 22. Assim, o projeto reserva o novo tipo penal a condutas relativas a bens, direitos ou valores oriundos, 
direta ou indiretamente, de crimes graves e com características transnacionais.

23. O projeto, desta forma, mantém sob a égide do art. 180 do Código Penal, que define o crime de receptação, as condutas que tenham por objeto a aquisição, o recebimento ou a ocultação, em proveito próprio ou alheio, de 'coisa que sabe ser produto de crime, ou influir para que terceiro, de boa-fé, a adquira, receba ou oculte'. Fica, portanto, sob o comando desse dispositivo a grande variedade de ilícitos parasitários de crimes contra o patrimônio.

[...]62. As modalidades de lavagem de dinheiro ou ocultação descritas no projeto serão punidas, ainda que desconhecido ou isento de pena o autor do crime básico (art. 2o, § 1o). A regra está em harmonia com o sistema do Código Penal, especificamente quanto à punibilidade da receptação, mesmo quando ignorada a autoria ou isento de sanção penal o responsável pelo crime de que proveio a coisa (art. 180, § 2o). Tanto a receptação como a lavagem e a ocultação caracterizam modalidades autônomas de aproveitamento de um delito anterior, cuja reação penal deve ser, por isso mesmo, independente do resultado do outro processo" (grifos nossos).

Do exposto, extrai-se que, no que se refere à prática da conduta, nada haveria de divergente entre a lavagem de dinheiro e a receptação, considerando os conteúdos formais e materiais dos tipos penais, exceção feita à natureza e à gravidade do ilícito primário, corroborando a tese do tipo penal meramente utilitarista da lavagem. Soma-se a isso a utilização indireta do princípio da especificidade 
associado à tutela dos crimes ínsitos à globalização - isto é, de proveniência associada às organizações criminosas e ao tráfico de drogas, como forma de populismo penal.

Ademais, tendo em conta a funcionalidade do crime em tela, não há como se evadir de comparações com os crimes de favorecimento real e pessoal, bem como de receptação, na medida em que estes têm funções estritamente semelhantes, mas, no entanto, de modo diverso ao que ocorre na lavagem, vedam expressamente o "auto encobrimento". De tal sorte, Vivian Schorscher (2012, p. 30) verifica que, não raro, os tipos penais acima elencados

são apontados por alguns representantes da doutrina como possivelmente suficientes para a reprimenda da conduta tipificada como lavagem de dinheiro, uma vez que este delito, do ponto de vista dogmático e tal qual previsto na Convenção de Viena de 1988, possui a mesma estrutura de referidos tipos penais.

De todo modo, referente à vedação do auto encobrimento no crime de receptação, Mir Puig interpreta que isto ocorre por tratar-se da "forma de asegurar o realizar un beneficio obtenido o perseguido por un hecho anterior y no lesionan ningún bien jurídico distinto al vulnerado por este hecho anterior ni aumentan el daño producido por el mismo" (apud CORDERO BLANCO, 1999, p. 467)

É sabido que a impossibilidade de auto encobrimento do exemplo retro é decorrente do princípio da consunção, o qual, segundo Stevenson (apud CARVALHO FILHO, 2009, p. 85-86), é verificado entre "normas que incriminam fatos anteriores e posteriores do agente, efetuados pelo mesmo fim prático", isto é, no chamado conflito aparente de normas. Nesta conjuntura, explica Cirino dos Santos (2008, p. 426), que "o antefato e o pós-fato co-punidos estão, 
geralmente, em relação de consunção com o fato principal: são punidos em conjunto com o fato principal".

Nesse sentido, o escopo do delito de lavagem de dinheiro em impedir o aproveitamento dos produtos de crimes anteriores enseja a compreensão da autolavagem como mero exaurimento do crime antecedente (GRECO FILHO, 2006; ROMANI NETTO, 2010; RODRÍGUEZ; LAW, 2013, p. 255) ou, em hipótese mais extensiva, como fato posterior copunido.

Destarte, o pós-fato copunido é apresentado por Cruz (2014, p. 785) como "casos em que, conquanto haja pluralidade de ações e aparente pluralidade de incidência típica, deve-se reconhecer a presença de um único delito por força de questões valorativas”. Tais questões valorativas devem ser compreendidas como a incorporação do injusto do tipo penal do crime posterior ao conteúdo de injusto do tipo legal primário (CIRINO DOS SANTOS, 2008, p. 426), ou como a "unidade de sentido do acontecimento ilícito global-final" (DIAS, 2007, p. 1016).

Isto é, em oposição ao que sustenta a doutrina favorável à aplicabilidade da autolavagem, a lesão a diverso bem jurídico não constitui elemento suficiente a afastar o reconhecimento de eventual copunibilidade, como defendem Jorge de Figueiredo Dias (2007, p. 1016-1017), Juarez Cirino dos Santos (2008, p. 426), Flavio Antônio da Cruz (2014, p. 805) e Jorge Godinho (2009, p. 93-94). Outrossim, a Súmula 17 do STJ reafirma a possibilidade do conflito aparente de normas conquanto não haja afetação ao mesmo bem jurídico.

Ademais, a justificativa da não recepção do instituto de consunção em casos de ofensa a bens jurídicos diversos supõe, inclusive, a impossibilidade de um tipo legal tutelar bens jurídicos nucleares e periféricos ou, ainda, da pluriofensividade de bens 
jurídicos, forma pela qual considerável doutrina procura legitimar o tipo penal da lavagem de dinheiro.

Em tais condições, Rios e Laufer (2011, p. 138) reforçam que, "não obstante a pluralidade de ações, poderá haver um só delito se o desvalor jurídico for único, ou se um fato posterior regulado em uma norma, na verdade se insira como circunstância do fato delitivo previsto em outra norma incriminadora considerada prevalente".

Quando se fala em pós-fato copenado, trata-se, portanto, da suficiência para o exaurimento do conteúdo do injusto do delito posterior através do tipo penal precedente, e não necessariamente da identidade de bens jurídicos ofendidos. Urge, pois, expor os brilhantes ensinamentos de Juarez Tavares acerca do injusto penal, bem como quanto aos conceitos de desvalor do ato e do resultado.

Para Tavares (2002, p. 298-299), “o injusto não é produzido pela simples causalidade, mas somente como obra de uma determinada pessoa, tendo em vista os seus objetivos, motivos ou deveres para com o fato, que apresentam mesma importância para o injusto que a lesão efetiva de bens jurídicos". Deste modo, "ao estabelecer as características da conduta proibida, inserindo-as no tipo de injusto, o legislador procede a uma avaliação negativa sobre essa conduta mesma e sobre o resultado por ela produzido. Esta dupla avaliação toma o nome de desvalor do ato e desvalor do resultado".

Com efeito, a fim de conceder autonomia ao delito de lavagem, o desvalor do injusto penal é, na verdade, pretensamente fragmentado entre seu tipo penal próprio e o tipo do crime antecedente. É evidente que a valoração do emprego do capital ilícito na economia é intrínseca ao tipo de injusto dos crimes precedentes, e seu desvalor, na lavagem de capitais, quando cometida pelo mesmo autor do crime primário, não tem vida própria, na medida em que esta é um mero mecanismo utilizado para a exclusiva finalidade de fruição de produto do crime. 
Não raro, para tornar possível a incorporação desta vantagem ilícita obtida, faz-se o uso de outras condutas posteriores, as quais são, neste momento, tipificadas em tipo penal diverso.

De tal sorte, Jescheck (apud RIOS; LAUFER, 2011, p. 164) sustenta que "a essência típica da relação entre o delito e a ação que lhe sucede consiste aqui em que o autor, por regra geral, também deve cometer o fato posterior para obter as vantagens derivadas do fato principal", isto é, "admitindo-se o concurso aparente em relação aos atos de aproveitamento e ocultação de outro crime" (RIOS; LAUFER, 2011, p. 164), em ajustada completude da intenção inicial do autor quando do cometimento do delito precedente. No mesmo sentido é a interpretação de Richard Honig, como demonstra Flavio Antônio da Cruz (2014, p. 794-795), de Jorge Godinho (2009, p. 87-88), de Eduardo Correia e José Lobo Moutinho (apud GoDINHO, 2009, p. 9097), dentre outros.

Rios e Laufer (2011, p. 173) intentam transferir a solução teórica empregada em casos de conflito aparente de normas ao plano concreto, assim exemplificando-a

por meio de um raciocínio valorativo se dessume estar o desvalor da conduta de falso devidamente integrado no delito de sonegação, independentemente de porventura terem sido lesionados ou colocados em perigo bens jurídicos diversos ou ainda se realizada mais de uma conduta do ponto de vista naturalístico.

Destarte, nota-se evidente similitude da aludida elucidação com o tipo penal objeto de estudo do presente artigo. Ora, a única divergência entre os casos se refere à questão de um ser fato anterior copenado, ao passo em que outro é fato posterior copenado. Nesse sentido, a supracitada conduta do falso teria funcionalidade ao possibilitar a prática de crime posterior, enquanto a lavagem seria o 
instrumento a possibilitar o proveito do produto do crime anterior, não havendo que se falar que o princípio da consunção funcionaria como estímulo às condutas criminosas.

Com efeito, assim já se manifestou o TRF-4 em algumas oportunidades:

"[...] Quanto ao crime inscrito no art. 293, V, do CP, verificado que, embora não constituísse meio para a consumação da apropriação indébita, deveu-se tão somente à necessidade de comprovar o depósito na Caixa dos valores repassados pela empresa contratante, garantindo, assim, a posse da quantia apropriada, correta a sentença ao considerar como pós-fato impunível, aplicando o princípio da consunção. [...] A alegação de que os tipos penais protegem bens jurídicos distintos não é suficiente par afastar a consunção, porquanto o princípio em apreço se destina justamente aos casos em que os tipos penais protegem bens jurídicos diversos." (APC 2000.71.05.005029-5/RS, 7æaT., rel. Des. Tadaaqui Hirose, Dj 16.11.2005)

"A aplicação da regra do concurso material de crimes não se mostra a melhor interpretação dos fatos, pois o conjunto probatório evidenciou que a falsidade inscrita no art. 299 do CP somente foi praticada para tentar evitar a responsabilização pela falsificação dos documentos públicos, razão por que se traduz em pósfato impunível" (APC 2001.72.09.001795-9/SC, 7ạT., rel. Des. Tadaaqui Hirose, Dj 20.09.2006).

Diante de toda conjuntura ostentada, a opção legislativa no tocante à autonomia e independência do delito de lavagem de dinheiro quanto ao crime antecedente não deve prosperar como razão 
argumentativa central a afastar a incidência interpretativa referente à ocorrência do pós-fato copenado, cuja consequência é a utilização do princípio da consunção em atenção ao princípio do ne bis in idem. Interpretação diversa levaria a crer que, na hipótese de tomar-se como verdade absoluta a escolha do legislador, não haveria espaço às Ações Diretas de Inconstitucionalidade, por exemplo. Há, portanto, que prevalecer a conjuntura que consagre interpretações capazes de adequar as escolhas legislativas às garantias fundamentais e, sobretudo, à razão de ser do Direito Penal.

Nesse sentido, Robles Planas (2016, p. 41) assevera que "uma das tarefas que mais singulariza o trabalho científico em Direito é analisar se as decisões do legislador correspondem aos critérios de legitimidade material desenvolvidos ao longo do tempo por uma cultura jurídica determinada, ou se são meros atos de poder”. Ademais, conforme devidamente demonstrado, a infindável indefinição dogmática quanto ao bem jurídico tutelado pelo tipo penal da lavagem de dinheiro não permite que tal contexto seja o plano central para definir ou não a possibilidade de punição do mesmo autor - e, inclusive, do próprio tipo penal como um todo. Portanto, enquanto perdurar a aludida imprecisão, não deve prosperar a incidência da criminalização a este agente, sob a hipótese de aplicação de um Direito Penal que, na dúvida, atua em favor da expansão do poder punitivo do Estado.

De outro tanto, ainda que não seja o objetivo deste trabalho, convém apresentar, ainda que de modo sucinto, alguns paradoxos derivados da possibilidade de criminalizar a autolavagem, isto é, os efeitos perversos ou contraproducentes da norma.

Inicialmente, ressalta-se que "dinheiro sujo" é mera linguagem figurada, isto é, não há propriamente cédulas sujas. Nesta circunstância, na posse de determinado agente, o referido dinheiro 
"sujo" passa a integrar seu capital como um todo. Em segundo plano, é valido apontar que utilizar bens e valores não é conduta excepcional. Tal procedimento integra atividade corriqueira e usual na sociedade capitalista. A atuação do agente na atividade econômica pertence à vida cotidiana do cidadão.

Somadas tais premissas, sobrevêm duas interpretações possíveis: como consequência ter-se-ia a perpetuação infinita de autolavagem ou; devidamente estabelecida (ou esclarecida) a hipótese de exaurimento do crime antecedente, o resultado seria uma norma contraproducente, que estimula o hedonismo e veda a atividade econômica produtiva (Cf. SGUBBI, 2015; GERACI, Art. 648-ter.1...).

Na primeira circunstância, exemplifica-se a possibilidade de expansão da criminalização quanto a diversas operações financeiras daquele que tiver cometido o crime antecedente, notadamente quando este é delito tributário-fiscal. Isto em razão da já citada conduta intrínseca ao sistema socioeconômico vigente - operações financeiras, por exemplo -, fazendo com que qualquer conduta na atividade econômica seja criminalizada. Outro exemplo dado por Sgubbi (2015, p. 141) seria a compra de um apartamento. A princípio, tal conduta não se adequa(ria) ao tipo penal de lavagem. No entanto, caso o mesmo imóvel seja alugado tempos depois, passaria a estar devidamente integrado ao fato típico.

Por outro lado, para aqueles que defendem a atividade econômica como bem jurídico tutelado, e aceitam eventuais possibilidades concretas de exaurimento do crime, a norma produziria efeito subversivo. $\mathrm{O}$ autor evitaria a utilização do capital na atividade econômica (frisa-se, novamente, na hipótese de devidamente predefinido o conceito de "utilização de bens na atividade econômica ou financeira"), mas utilizaria o proveito do crime como gozo próprio, prazeres individuais, através de viagens, por exemplo. Todavia, aqui 
recairia outro problema: o consumismo exacerbado poderia também produzir elemento probatório contra si mesmo, e, por outro lado, a controversa delimitação do exaurimento do crime seria circunstância que induziria o autor a manter o dinheiro na economia submersa, isto é, reinvestindo-o em condutas criminosas.

Conforme se pretendeu enfatizar no presente estudo, a opção legislativa pela criminalização da lavagem de dinheiro é pautada na repressão à criminalidade, na tentativa de obstar o aproveitamento do produto ilícito subsequente a determinado delito precedente. Segundo Gómez de la Torre e Fabián Caparrós (2010, p. 68),

como la receptación, el blanqueo constituye una actividad de segundo grado, en la medida en que sólo existe si hay unos bienes que tengan su origen en un delito anterior. En ambos casos se produce un encubrimiento de la infracción previa, y podría también aceptarse - al menos, en el plano criminológico - que ambas conectan con la obtención de una ventaja económica, en tanto implican la actuación sobre los bienes obtenidos para obtener su disfrute directo o mediato.

Destarte, na hipótese de um agente cometer um ato criminoso cuja consequência é a obtenção de vantagem financeira, não há dúvida de que seu objetivo final seja a utilização deste benefício ilegal. Daí que a finalidade da lavagem de capitais é a inserção do capital ilícito, aparentemente com origem lícita, no sistema econômico. Não é excedente sustentar que o crime de lavagem não possui existência própria, sendo necessariamente condicionado a eventual crime precedente. E, uma vez manifesta a problemática da ausência de bem jurídico a ser tutelado, tem sua razão de ser como utilitarista, em 
perfeita harmonia com o pragmatismo e eficientismo do homem pósmoderno brevemente apontados no capítulo primeiro.

O crime de branqueamento de capitais é, portanto, consequentemente, um acompanhante típico do crime do delito antecedente, notadamente na hipótese de cometimento pelo mesmo autor.

Segundo Godinho (2009, p. 105), o tratamento excepcional da lavagem de dinheiro, contrastado aos crimes supracitados, "relevaria ainda de um 'patrimonialismo' cego, mais empenhado no confisco das vantagens e mais atento aos aspectos financeiros do que à punição dos agentes do crime, que não toleraria a dissimulação da origem das vantagens, mas já toleraria a fuga do agente". Outra interpretação possível é fundada, novamente, na própria função simbólica do tipo penal e em sua natureza utilitarista.

Nesta conjuntura, a vedação à autolavagem no ordenamento jurídico penal representaria uma afronta à sociedade que gira em torno da eficiência, cultuada enquanto essência do neoliberalismo, de modo a cultivar a máxima de que os fins justificam os meios. Tal circunstância refletiria a ideia de que os autores da lavagem sairiam impunes, podendo reproduzir à sociedade uma mensagem negativa.

No entanto, conforme o próprio nome carregado pela tese diz, trata-se de um fato posterior copenado. A pena do crime precedente já abrange esta conduta ulterior. Talvez por tal razão, Godinho se atenta à questão linguística, propondo a inutilização do termo "pós-fato impune", para reforçar a compreensão de que o conteúdo de ilicitude do fato secundário está devidamente incorporado na ilicitude do tipo penal primário.

De tal sorte, não há que se falar em impunidade em referência à presente situação. Conforme esclarece Flavio Antônio da Cruz (2014, p. 801), 
o sistema tolera a exoneração de pena, a despeito da aparência de concurso real.

O contrário é inadmissível! O juízo não pode invocar uma pretensa vedação de 'punição insuficiente', com o fim de multiplicar crimes. Ou seja, o juízo não pode invocar o tot poena quot delicta com o escopo de vaticinar presunções e analogias in malam partem. Apenas o contrário é cabível, frente à indispensável tutela da segurança jurídica e dos vetores inerentes ao Estado de Direito.

Entre o ne bis in idem e o tot poena quot delicta, o primeiro tende a conter o poder punitivo - e, portanto, a exercer uma função emancipatória -, enquanto que o segundo tende a ampliá-lo, afrontando postulados iluministas.

A alegação de punição insuficiente e sua possível (indevida) inserção ao tot poena quot delicta talvez explique a previsão de pena mais branda à autolavagem no Codice Penale italiano, como anteriormente apontada.

De todo o exprimido, resta concluir, portanto, pela inaplicabilidade do branqueamento de capitais ao autor igualmente responsável pelo cometimento do delito prévio, sendo certo que a lavagem constituiria "un acto posterior copenado ya incluido en el desvalor del delito precedente $y$, por lo tanto, impune" (BAJO FERNÁNDEZ; BACIGALUPO, 2001, p. 689).

Por fim, não se intenta estimular a prática das condutas previstas na Lei de Lavagem de dinheiro, até por entender que tais atos já se encontram devidamente tipificados no ordenamento jurídico pátrio, com previsões nos tipos penais de receptação, favorecimento 
real, falsificação ideológica e documental e demais crimes referentes ao sistema financeiro.

Não raro, no afã da guerra à criminalidade e à impunidade, discursos e práticas que buscam a efetivação de direitos fundamentais e garantias fundamentais acabam por receber a etiqueta de condutas contraproducentes, como se a consagração dos direitos fundamentais representasse uma flexibilização no sentido de promover ações criminosas e, consequentemente, por si só, represente um ato criminoso. Não é demasiado afirmar que, no sentido contrário, é a violação de tais direitos que se enquadra na prática de crime.

Portanto, a lesão ao injusto penal do delito de lavagem, quando em conta o mesmo autor, é devidamente consumida no injusto do crime antecedente, considerando os objetivos e motivos do agente em ter cometido o delito anterior, de modo que eventual punição representaria cristalina violação ao princípio do ne bis in idem.

Não obstante o silêncio legislativo quanto à impossibilidade da punição por lavagem de capitais ao agente que cometeu o delito precedente, há que se valer da analogia in bonam partem - conforme preveem tal possibilidade Roxin, Jescheck, Jakobs, Andrei Schmidt, Zaffaroni e Juarez Cirino dos Santos (CRUZ, 2011, p. 78) -, relacionada aos tipos penais de receptação e de favorecimento real e pessoal, para que o Direito Penal não seja utilizado às avessas, expandido o poder punitivo do Estado contra as liberdades individuais e, desta forma, seja vedada a punição em referência.

\section{CONSIDERAÇÕES FINAIS}

Segundo Zaffaroni (1998, p. 204), o sistema penal representou, no segundo milênio, o grande ídolo, onipotente e onisciente, que 
resolveria todos os problemas da sociedade. Sua perpetuidade significaria, no entanto, uma prática suicida da humanidade, considerando suas perspectivas repressora e vindicativa. Deste modo, para o magistrado argentino, nossa sobrevivência é condicionada ao fim do sistema penal. Contudo, em momento antecedente, deveríamos pôr fim ao "discurso punitivo e achar soluções reais para os problemas, não ilusões para solucioná-los", notadamente em afronta ao caráter simbólico do Direito Penal, e de modo a conter o exercício do poder punitivo do Estado.

Para tanto, é plenamente viável que o primeiro passo nessa direção seria a restrição do alcance do sistema penal pautada no mero emprego de uma hermenêutica voltada à consagração das garantias fundamentais e ao respeito dos princípios penais e constitucionais, ainda que as opções legislativas caminhem no sentido contrário, sustentadas pelo anseio popular que ainda não se deu conta da direção que toma.

Destarte, em que pese seja o delito de lavagem de dinheiro interpretado como uma conquista visando à minimização dos desequilíbrios sociais (característica essa ínsita ao modelo capitalista), não é demasiado sustentar que esta seja uma opção que legitima, cada vez mais, o poder punitivo, o controle social formal através dos instrumentos persecutórios estatais. Tal opção, cujos efeitos exterminam direitos fundamentais e desrespeitam critérios de legitimidade para permitir a intervenção penal, tende a refletir na grande e conhecida clientela do sistema penal que (sobre)vive em meio ao cotidiano da Justiça Criminal, e, ao mesmo tempo, não resolve conflitos que - indevidamente - se propõe a solucionar.

Assim, práticas jurídico-legislativas que optam por criminalizar condutas como a autolavagem de dinheiro - e aqui poderia se falar apenas no delito de lavagem de capitais propriamente dito - 
distanciam-se cada vez mais de um Estado democrático de Direito. A "ocultação" e "dissimulação" constantes do tipo penal em referência talvez se relacionem à própria finalidade da norma, e não ao seu manifesto conteúdo. Trata-se de mera tecnocracia no Direito Penal, "não tanto visando modificar a realidade, senão tentando modificar a imagem da realidade nos espectadores: não procuram tanto satisfazer as necessidades reais e a vontade política dos cidadãos, senão vir ao encontro da denominada 'opinião pública'” (BARATTA, 1994, p. 22).

Promove-se igualdade às avessas, quando, ao invés de se efetivar um sistema jurídico garantista e democrático, promove-se a flexibilização de garantias fundamentais a (quase) todo cidadão. Um tipo penal (lavagem) não pode ser um instrumento eficaz no combate à macrocriminalidade, como pretendem certos autores, notadamente quando já se tem tipos penais que, na hipótese de acreditar na capacidade preventiva do Direito Penal, incriminariam cada fase do crime de lavagem (cf. MARTINELLI, 2011).

De todo modo, os riscos causados à ordem econômica, supostamente oriundos exclusivamente de condutas ilícitas e criminalizadas, têm maior capacidade de promoção de temor e tensão sociais enquanto presentes numa sociedade idealizada e composta cada vez mais pela figura do auto-empresário, o qual, segundo Ulrich Beck, "acredita na grande mentira segundo a qual ele pode sobreviver no mercado mundial diante das previsíveis inseguranças extremas e diante das dependências extremas em que se encontra em face dos verdadeiros global players" (BECK. 2003, p. 74). Nessa conjuntura, e em razão da íntima e direta relação do crime de lavagem de dinheiro com altas cifras econômicas, tem-se que, não raro, vinculam-se a ele a criação de um falso inimigo e de novo bode expiatório (ZAFFARONI et al., 2013, p. 46-51), bem como a midiatização e seus intrínsecos efeitos deletérios (cf. Cirino, A justiça penal...). 
Assim, conforme observa Martinelli (2011, p. 131), quando se fala em lavagem, a 'guerra' é do Estado contra os donos do capital ilícito. Estes são os inimigos eleitos e, para eliminá-los, vale qualquer estratégia, inclusive a edição de leis inconsistentes e ilegítimas. Diante de uma situação excepcional, o Estado ignora os princípios do Estado democrático de Direito e sanciona, com excesso de rigor, todas as condutas que considerar prejudiciais aos seus interesses.

Ademais, a possibilidade de criminalização da autolavagem corrobora a tese da instrumentalidade do tipo penal em questão, funcionando como um tipo de captura, cuja função é a própria punição ao autor do delito antecedente. De modo contrário, não haveria motivos para não se considerar a autolavagem como um autêntico bis in idem, tratando-se claramente de um fato cujo injusto penal e o desvalor estão inseridos no tipo penal do delito antecedente.

Os anseios da sociedade pós-moderna não devem ser fundamento hábil a exterminar direitos e a validar o abandono de garantias conquistadas em históricos e sangrentos combates ao Estado policial, que tende a restringir liberdades pessoais, colocando-nos novamente em direção a uma democracia autoritária. Em sentido contrário, os aludidos anseios populares e suas consequentes demandas talvez sejam fruto do percurso da sociedade em meio a um sistema político-socioeconômico no mínimo indevido, equivocado e falacioso, ainda mais quando considerado que os famigerados riscos combatidos são inerentes ao próprio sistema em questão.

\section{REFERÊNCIAS BIBLIOGRÁFICAS}


AMORIM, Maria Carolina de Melo. A inexigibilidade de conduta diversa: os fundamentos para a aplicação das causas supralegais no Direito Penal brasileiro. Belo Horizonte: Del Rey, 2014.

BADARÓ, Gustavo; BOTTINI, Pierpaolo. Lavagem de dinheiro: aspectos penais e processuais penais; comentários à Lei 9.613/1998 com as alterações da Lei 12.683/2012. São Paulo: Revista dos Tribunais, 2012.

BAjo Fernández, Miguel; BaCigalupo, Silvina. Derecho penal económico. Madrid: Centro de Estudios Ramón Areces, 2001.

BARATTA, Alessandro. Funções instrumentais e simbólicas do direito penal: lineamentos de uma teoria do bem jurídico. Revista Brasileira de Ciências Criminais, São Paulo, v. 2, n. 5, p. 5-24, jan./mar. 1994.

BeChARA, Ana Elisa Liberatore Silva. Critérios político-criminais da intervenção penal no âmbito econômico: uma lógica equivocada. In: FrANCO, Alberto Silva; LIRA, Rafael de Souza. Direito penal econômico: questões atuais. São Paulo: Revista dos Tribunais, 2011. p. 41-69.

BECK, Ulrich. La sociedad del riesgo: hacia una nueva modernidad. Barcelona: Paidós, 2002.

. Liberdade ou capitalismo. Ulrich Beck conversa com Johannes Willms. Tradução Luiz Antônio Oliveira de Araújo. São Paulo: UNESP, 2003.

BozZA, Fábio da Silva; ZILIO, Jacson Luiz. A influência do neoliberalismo na política criminal contemporânea. In: FERNANDES, Márcia Adriana et al. Escritos transdisciplinares de criminologia, direito e processo penal: homenagem aos mestres Vera Malaguti e Nilo Batista. Rio de Janeiro: Revan, 2014. p. 387-397. 
BRANDÃO, Nuno. Branqueamento de capitais: o sistema comunitário de prevenção. Coimbra: Coimbra Editora, 2002.

CARValho Filho, José Cândido de. Concurso aparente de normas penais. Rio de Janeiro: Revan, 2009.

Cirino dos Santos, Juarez. Direito Penal Parte Geral. 3a Ed. Curitiba: ICPC e Lumen Juris, 2008.

A justiça penal como espetáculo. Disponível em: $<$ http://icpc.org.br/wp-content/uploads/2015/05/A-Justic\%CC\%A7aPenal-como-Espeta\%CC\%81culo.pdf>. Visto em: 15 dez 2016.

A utilização da obstrução da justiça como meio de ataque às garantias fundamentais. Disponível em: <http://icpc.org.br/wpcontent/uploads/2016/12/A-utiliza\%C3\%A7\%C3\%A3o-daobstru\%C3\%A7\%C3\%A3o-da-justi\%C3\%A7a-como-meio-deataque-\%C3\%A0s-garantias-fundamentais.pdf $>$. Visto em: $15 \mathrm{dez}$ 2016.

. Novas hipóteses de criminalização. Disponível em: < http://icpc.org.br/wpcontent/uploads/2013/01/novas_hipoteses_criminalizacao.pdf>. Visto em: 16 dez 2016.

Ciro, Santoriello. La disciplina di contrasto del riciclaggio prima dell'introduzione del reato di autoriciclaggio. In Altalex, 10 jun 2015. Disponível em $<$ http://www.altalex.com/documents/news/2015/06/08/antiriciclaggio >. Visto em 12 dez 2016.

Christie, Nils. A indústria do controle do crime: a caminho dos GULAGs em estilo ocidental. Rio de Janeiro: Forense, 1998. 
Costa, Helena Regina Lobo da. Teoria do injusto penal. In: SilveIRA, Renato de Mello Jorge; NETTO, Alamiro Velludo Salvador; SoUZA, Luciano Anderson de. Direito penal na pós-modernidade: escritos em homenagem a Antonio Luis Chaves Camargo. São Paulo: Quartier Latin, 2015. p. 211-221.

Cordero Blanco, Isidoro. El delito de blanqueo de capitales. Pamplona: Aranzadi, 1997.

CRUZ, Flavio Antonio. Provocações sobre a interpretação das fontes do direito penal econômico: entre a relatividade hermenêutica e o dogma constitucional da taxatividade. In: FRANCO, Alberto Silva; LIRA, Rafael de Souza. Direito penal econômico: questões atuais. São Paulo: Revista dos Tribunais, 2011. p. 71-135.

. O confronto entre o concurso formal de crimes e o concurso aparente de normas penais no direito brasileiro: revisão crítica sob os influxos de uma hermenêutica emancipatória. 2014. Tese (doutorado em Direito) - UFPR, Curitiba, 2014.

D’ÁVILA, Fabio Roberto. Liberdade e segurança em direito penal: o problema da expansão da intervenção penal. In Revista Eletrônica de Direito Penal AIDP-GB, ano 1, vol. 1, no1, junho 2013. p. 65-73.

DeLEUZE, Gilles. Post-Scriptum sobre as sociedades de controle. In: Conversações: 1972- 1990. Trad. Peter Pál Pelbart. Rio de Janeiro: Editora 34, 1992. p. 219-226.

DIAS, Jorge de Figueiredo. O direito penal entre a sociedade industrial e a sociedade do risco. Revista Brasileira de Ciências Criminais, São Paulo, n. 33, p. 39-65, jan./mar. 2001. 
- Direito penal: parte geral: tomo I: questões fundamentais, a doutrina geral do crime. 2. ed. Coimbra: Revista dos Tribunais / Coimbra Ed., 2007.

. Para um sistema renovado do facto punível. Revista Brasileira de Ciências Criminais, São Paulo, v. 23, n. 112, p. 107-123, jan./fev. 2015.

DIETER, Maurício Stegemann. A inexigibilidade de comportamento adequado à norma penal e as situações supralegais de exculpação. 2008. Tese (mestrado em Direito) - UFPR, Curitiba, 2008.

EsPOSITO, Gianluca. Il riciclaggio del denaro proveniente da attività illecite e la Convenzione del Consiglio d' Europa in ordine alla individuazione, sequestro e confisca dei proventi del crimine (1990). Archivio Penale, Roma, n. 4, p. 427-430, abr. 1994.

Estellita, Heloísa. O direito humano de não cooperar na própria incriminação, a proteção ao domicílio e a fiscalização tributária. Revista Brasileira de Ciências Criminais. São Paulo, v. 26, p. 129-142, abr./jun 1999.

. Proibir autolavagem resolveria injustiças trazidas pela nova lei. In: Revista Consultor Jurídico. 15 jun 2014. Disponível em: http://www.conjur.com.br/2014-jun-15/entrevista-heloisa-estellitaadvogada-criminalista-professora. Visto em: 29 nov 2016.

FrANCO, Alberto Silva. Globalização e criminalidade dos poderosos. Revista Brasileira de Ciências Criminais, São Paulo, v. 8, n. 31, p. 102-136, jul./set. 2000.

FRAGOSO, Fernando. Considerações sobre o crime de lavagem de dinheiro imputado a XPX (nome fictício). Rio de Janeiro, 10 out 2013. Disponível 
http://www.fragoso.com.br/ptbr/arq_pdf/artigos/CONSIDERACOES_ _SOBRE_O_CRIME_DE_LAVAGEM_DE_DINHEIROPARECER.pdf.

GARLAND, David. A cultura do controle: crime e ordem social na sociedade contemporânea. Rio de Janeiro: Instituto Carioca de Criminologia / Revan, 2008.

GERACI, Marianna. Art. 648-ter.1 c.p.: breve analisi degli elementi costitutivi della fattispecie di autoriciclaggio e criticità ad essi collegate. In Giurisprudenza Penale. Disponível em $<$ http://www.giurisprudenzapenale.com/wpcontent/uploads/2016/02/GP_analisi-autoriciclaggio_geraci.pdf $>$. Visto em 9 dez 2016.

GoDINHO, Jorge A. F. Sobre a punibilidade do autor de um crime pelo branqueamento das vantagens dele resultantes. In: ANDRADE, Manuel da Costa; Antunes, Maria João; SousA, Susana Aires de. Estudos em homenagem ao Prof. Doutor Jorge Dias de Figueiredo Dias - volume III. Coimbra: Coimbra Editora, 2009. p. 363-399.

GoMes, Luiz Flávio. A lavagem de capitais como expressão do direito penal globalizado: enfoque crítico. In: SHECAIRA, Sérgio Salomão (Org.). Estudos criminais em homenagem a Evandro Lins e Silva: criminalista do século. São Paulo: Método, 2001. p. 225-236.

GÓMEZ DE LA TORRE, Ignacio Berdugo; FABIÁn CAPARRós, Eduardo A. La "emancipación" del delito de blanqueo de capitales en el derecho penal español. Revista Brasileira de Ciências Criminais, São Paulo, v. 18, n. 87, p. 57-83, nov./dez. 2010.

GRECO, Luís. Reflexões provisórias sobre o crime de enriquecimento ilícito. Boletim IBCCRIM, São Paulo, v. 23, n. 277, p. 07-08., dez. 2015. 
Greco FilHo, Vicente. Tipicidade, bem jurídico e lavagem de dinheiro. In: CostA, José de Faria; Silva, Marco Antonio Marques da. Direito penal especial, processo penal e direitos fundamentais: visão luso-brasileira. São Paulo: Quartier Latin, 2006. p. 147-169.

Gullo, Antonio. Autoriciclaggio. $21 \mathrm{dez}$ 2015. Disponível em: < http://www.penalecontemporaneo.it/upload/1450520894GULLO_20 15a.pdf>. Visto em $12 \mathrm{dez} 2016$.

HARVEY, David. O neoliberalismo: história e implicações. Tradução Adail Sobral e Maria Stela Gonçalves. São Paulo: Loyola, 2008.

HASSEMER, Winfried. Desenvolvimentos previsíveis na dogmática do direito penal e na política criminal. Revista eletrônica de direitos humanos e política criminal - REDHPC. Porto Alegre, no 2, 2008. Disponível em: $<$ http://www.buscalegis.ufsc.br/revistas/files/anexos/32318-38755-1PB.pdf $>$. Acesso em $10 \mathrm{dez} 2016$.

JAKOBS, Günther. Direito Penal do Cidadão e Direito Penal do Inimigo. In: JAKOBS, Günther; MELIÁ, Manuel Cancio. Direito Penal do Inimigo: noções e críticas. org. e trad. André Luís Callegari, Nereu José Giacomolli. 2a ed. Porto Alegre: Livraria do Advogado, 2007.

KARAM, Maria Lúcia. A esquerda punitiva. Discursos Sediciosos: crime, direito e sociedade, Rio de Janeiro, v. 1, n. 1, p. 79-92, 1996.

MARTINELLI, João Paulo Orsini. Lavagem de dinheiro: análise crítica do bem jurídico. Jundiaí: In House, 2011.

. Lavagem de dinheiro: a questão do bem jurídico tutelado. Revista Síntese de direito penal e processual penal. Porto Alegre, v. 11, n. 72, p. 43-61, fev./mar. 2012. 
Martínez-Bujan PÉReZ, Carlos. Derecho penal económico y de la empresa. Valencia: Tirant lo Blanch, 2013.

MÉSZÁROS, István. A crise estrutural do capital. Tradução Francisco Raul Cornejo et al. 2.ed. rev. e ampliada. São Paulo: Boitempo, 2011.

MiNISTÉRIO DA FAZENDA. Exposição de motivos da Lei 9.613, de 1998. Disponível em: <http://www.coaf.fazenda.gov.br/menu/legislacao-enormas/legislacao-

1/Exposicao\%20de\%20Motivos\%20Lei\%209613.pdf/view>. Visto em: 10 dez 2016.

MORO, Sérgio F. Lavagem de Dinheiro. Saraiva: Curitiba, 2010.

NeTTO, Alamiro Velludo Salvador; Costa, Helena Regina Lobo da; SARCEDO, Leandro. Lavagem de dinheiro no direito penal brasileiro: reflexões necessárias. Boletim IBCCRIM, São Paulo, v. 21, n. 250, p. 23, set. 2013.

NETTO, José Paulo. Crise do socialismo e ofensiva neoliberal. 2. ed. São Paulo: Cortez, 1995.

PAChUKANIS, E. B. Teoria geral do Direito e marxismo. Tradução Silvio Donizete Chagas. São Paulo: Acadêmica, 1988.

PASSETTI, Edson. Sociedade de controle e abolição da punição. In São Paulo em Perspectiva, 13(3) 1999. p. 56-66.

PlanAS, Roberto Robles. Estudos de dogmática jurídico-penal: fundamentos, teoria do delito e direito penal econômico. Coleção Ciência Criminal Contemporânea, v. 6. Belo Horizonte: D’Plácido, 2016.

PritTwitZ, Cornelius. A função do Direito Penal na sociedade globalizada do risco: defesa de um papel necessariamente modesto. In: 
AmbOS, Kai; BÖHM, Maria Laura (coord.). Desenvolvimentos atuais das ciências criminais na Alemanha. Brasília: Gazeta Jurídica, 2013. p. 5366.

QUEIJO, Maria Elizabeth. O direito de não produzir prova contra si mesmo: o princípio 'nemo tenetur se detegere' e suas decorrências no processo penal. 2. ed. São Paulo: Saraiva, 2012.

RENART García, Felipe. El blanqueo de capitales en el derecho suizo. Revista del Poder Judicial, Madrid, n. 50, p. 119-165, 2o trim. 1998.

RIOS, Rodrigo Sánchez; LAUFER, Daniel. Apontamentos a respeito do concurso de crimes e do conflito aparente de normas: a regra do antefato e do pós-fato coapenado no âmbito dos delitos econômicos. In FRANCO, Alberto Silva; LIRA, Rafael (org.). Direito penal econômico: questões atuais. São Paulo: RT, 2011, p. 138-199.

RODRÍGUEZ, Víctor Gabriel de Oliveira; LAW, Thomas. Autolavagem e evasão de divisas: elementos mínimos de interpretação para a autonomia da lavagem de dinheiro, diante da lei brasileira. In: OliVeIRA, William Terra de et al. Direito penal econômico: estudos em homenagem aos 75 anos do Professor Klaus Tiedemann. São Paulo: LiberArs, 2013. p. 247-261.

Romani NeTTO, Aldo. A lavagem de dinheiro como mero exaurimento da conduta antecedente. 2010. Artigo científico (Especialização GV Law Direito Penal Econômico) - Fundação Getúlio Vargas, São Paulo, 2010.

Roxin, Claus. Política criminal e sistema jurídico-penal. Tradução Luís Greco. Rio de Janeiro: Renovar, 2000. 
. A proteção de bens jurídicos como função do direito penal. Porto Alegre: Livraria do Advogado, 2009.

SANTOS, Fábio Antonio Tavares dos. O crime de evasão de divisas sob a ótica do direito penal mínimo. São Paulo: LiberArs, 2015.

SATZGER, Helmut. A europeização do direito penal: a influência do direito da União Europeia no ordenamento jurídico-penal nacional dos Estados membros. In AmBOS, Kai; BÖHM, Maria Laura (coord.). Desenvolvimentos atuais das ciências criminais na Alemanha. Brasília: Gazeta Jurídica, 2013. p. 175-190.

SCHIMIDT, Andrei Zenker. Direito Penal econômico: parte geral. Porto Alegre: Livraria do Advogado, 2015.

SCHORSCHER, Vivian C. A criminalização da lavagem de dinheiro: críticas penais. 2012. Tese (doutorado em Direito) - Faculdade de Direito da Universidade de São Paulo. São Paulo, 2012.

SouZA, Luciano Anderson de. Considerações dogmáticas quanto ao crime de receptação. In: SiLveIRA, Renato de Mello Jorge; NETTO, Alamiro Velludo Salvador; SoUZA, Luciano Anderson de. Direito penal na pós-modernidade: escritos em homenagem a Antonio Luis Chaves Camargo. São Paulo: Quartier Latin, 2015. p. 285-303.

SGUBBI, Filippo. Il nuovo delitto di "autoriciclaggio": una fonte inesauribile di "effetti perversi" dell'azione legislativa. In Diritto Penale Contemporaneo, 1/2015, p. 137-141.

SICA, Leonardo. Caráter simbólico da intervenção penal na orem econômica. In PRADO, Luiz Regis; DOTTI, René Ariel (orgs.). Teoria geral da tutela penal transindividual. São Paulo: Revista dos Tribunais, 2011. (Coleção doutrinas essenciais: direito penal econômico e da empresa; v. 1. p. 585-603. 
SILVA SÁNCHEZ, Jesús María. A expansão do direito penal: aspectos da política criminal nas sociedades pós-industriais. 3. ed. São Paulo: Revista dos Tribunais, 2013.

Silva JÚNIOR, Délio Lins e Silva; PAUlA, Marco Aurélio Borges de. Da inexigibilidade de conduta diversa no crime de lavagem de dinheiro praticado pelo mesmo autor do crime antecedente. In: SILVA, Luciano Nascimento; BANDEIRA, Gonçalo Nicolau Cerqueira Sopas de Melo. Lavagem de dinheiro e injusto penal: análise dogmática e doutrina comparada luso-brasileira. Curitiba: Juruá, 2009. p. 59-71.

SilveirA, Renato de Mello Jorge. A construção do Bem jurídico espiritualizado e suas críticas fundamentais. Boletim IBCCRIM, São Paulo, v. 10, n. 122, p. 14-15., jan. 2003.

SUTHERLAND, Edwin H. Crime de colarinho branco: versão sem cortes. Rio de Janeiro: Revan, 2015.

TAVARES, Juarez. Teoria do injusto penal. 2. ed. Belo Horizonte: Del Rey, 2002.

TORON, Alberto Zacharias. Corrupção e lavagem: é possível punir o agente da primeira também pelo crime parasitário? Revista do Advogado. São Paulo, v. 34, n. 125, p. 17-24, dez. 2014.

TRINGALI, Giovanni. Il reato di riciclaggio. Disponível em: $<$ http://www.studiocataldi.it/articoli/22334-il-reato-diriciclaggio.asp >. Visto em 14 dez 2016.

ZAFFARONI, Eugenio Raúl. Globalização e sistema penal na América Latina: da segurança nacional à urbana. Discursos Sediciosos: crime, direito e sociedade, Rio de Janeiro, v. 2, n. 4, p. 25-36, 1997. 
. Desafios do direito penal na era da globalização. Cidadania e justiça: revista da associação dos magistrados brasileiros, Rio de Janeiro, v. 2, n. 5, p. 200-204, 2o sem. 1998.

. Et. al. Direito penal brasileiro: primeiro volume: teoria geral do direito penal. 4. ed. Rio de Janeiro: Revan, 2013. 